\title{
Recent advances and future of immunotherapy for glioblastoma
}

\section{Neha Kamran, Alexandra Calinescu, Marianela Candolfi, Mayuri Chandran, Yohei Mineharu, Antonela S Assad, Carl Koschmann, Felipe Nunez, Pedro Lowenstein \& Maria Castro}

To cite this article: Neha Kamran, Alexandra Calinescu, Marianela Candolfi, Mayuri Chandran, Yohei Mineharu, Antonela S Assad, Carl Koschmann, Felipe Nunez, Pedro Lowenstein \& Maria Castro (2016): Recent advances and future of immunotherapy for glioblastoma, Expert Opinion on Biological Therapy, DOI: 10.1080/14712598.2016.1212012

To link to this article: http://dx.doi.org/10.1080/14712598.2016.1212012

Accepted author version posted online: 13

Jul 2016.

Published online: 13 Jul 2016.

Submit your article to this journal $₫$

Џll Article views: 3

Q View related articles ¿

View Crossmark data $₫$ 
Publisher: Taylor \& Francis

Journal: Expert Opinion on Biological Therapy

DOI: $10.1080 / 14712598.2016 .1212012$

Review

\section{Recent advances and future of immunotherapy for glioblastoma}

Neha Kamran ${ }^{1,2}$, Alexandra Calinescu ${ }^{1,2}$, Marianela Candolfi ${ }^{3}$, Mayuri Chandran ${ }^{1,2}$, Yohei Mineharu $^{4}$, Antonela S Assad ${ }^{3}$, Carl Koschmann ${ }^{1,2}$, Felipe Nunez ${ }^{1,2}$, Pedro Lowenstein ${ }^{1,2}$ and Maria Castro ${ }^{1,2}$.

${ }^{1}$ Department of Neurosurgery, The University of Michigan School of Medicine, MSRB II, RM 4570C, 1150 West Medical Center Drive, Ann Arbor, MI 48109-5689, USA. ${ }^{2}$ Department of Cell and Developmental Biology, The University of Michigan School of Medicine, MSRB II, RM 4570C, 1150 West Medical Center Drive, Ann Arbor, MI 48109-5689, USA. ${ }^{3}$ Instituto de Investigaciones Biomédicas (CONICET-UBA), Facultad de Medicina, Universidad de Buenos Aires, Argentina. ${ }^{4}$ Department of Neurosurgery, Kyoto University Graduate School of Medicine 54 Kawahara-cho, Shogoin, Sakyo-ku, Kyoto 606-8507, Japan.

Key words: Glioma, immunotherapy, gene therapy, cancer vaccines, passive immunotherapy, checkpoint blockade 
Correspondence should be addressed to Maria G Castro (mariacas@umich.edu).

Tel: 734.764 .0850

Fax: 734.764.7051

\section{Abstract}

Introduction: Outcome for glioma (GBM) remains dismal despite advances in therapeutic interventions including chemotherapy, radiotherapy and surgical resection. The overall survival benefit observed with immunotherapies in cancers such as melanoma and prostate cancer has fuelled research into evaluating immunotherapies for GBM.

Areas covered: Preclinical studies have brought a wealth of information for improving the prognosis of GBM and multiple clinical studies are evaluating a wide array of immunotherapies for GBM patients. This review highlights advances in the development of immunotherapeutic approaches. We discuss the strategies and outcomes of active and passive immunotherapies for GBM including vaceination strategies, gene therapy, check point blockade and adoptive $\mathrm{T}$ cell therapies. We also focus on immunoediting and tumor neoantigens that can impact the efficacy of immunotherapies.

Expert opinion: Encouraging results have been observed with immunotherapeutic strategies; some clinical trials are reaching phase III. Significant progress has been made in unraveling the molecular and genetic heterogeneity of GBM and its implications to disease prognosis. There is now consensus related to the critical need to incorporate tumor heterogeneity into the design of 
therapeutic approaches. Recent data also indicates that an efficacious treatment strategy will need to be combinatorial and personalized to the tumor genetic signature.

Keywords: Glioma, Immunotherapy, Cancer Vaccines, Checkpoint blockade, Gene Therapy,

\section{Introduction}

Gliomas are the most frequently diagnosed human primary brain tumors ${ }^{1}$. Glioma is derived from the greek word for "glue", as glial tumors are derived from CNS cells that form the scaffolding and structural support for neurons. Gliomas are diagnosed according to the predominant cell population (astrocyte or oligodendrocyte) and are graded according to pathologic features that correlate with tumor aggressiveness and clinical outcome, including nuclear atypia, microvascular proliferation, hemorrhages and necrosis ${ }^{1}$. Lower-grade gliomas (WHO grade II/III) are molecularly similar and frequently progress to glioblastoma (GBM, WHO grade IV).

Recently, efforts have been made to sub-group grade II-III ("lower grade") gliomas based on shared molecular features. In particular, sub-groups are based on the molecular status of: (1) deletion of chromosomes arms $1 p$ and $19 q(1 p / 19 q$ co-deletion), (2) mutation in codon 132 of the isocitrate dehydrogenase 1 gene (IDH1), and (3) activating mutations in the promoter of the TERT gene, which encodes telomerase ${ }^{2,3}$. Sub-grouping according to these features is predictive of histologic sub-type and prognosis, and molecular characteristics are increasingly used in the diagnostic work-up of gliomas (Table 1) ${ }^{4}$. For example, IDH1 mutational status has become a key feature in determining the prognostic and biologic features of lower-grade glioma ${ }^{2,3,5,6}$. 
IDH1 mutation is found in a majority of lower-grade glioma and secondary GBM, and is a positive prognostic variable $\mathrm{e}^{2,3}$. Gliomas which carry $1 \mathrm{p} / 19 \mathrm{q}$ co-deletion are oligodendrocytic in lineage, and carry the best prognosis and response to alkylator-based chemotherapy and radiation $^{7}$. Lower-grade IDH1-mutated gliomas without co-deletion are predominantly astrocytic tumors, and frequently carry concurrent mutations in the tumor suppressor TP53 and in the histone chaperone protein $A T R X^{4,5}$. Mutation (and loss) of ATRX was recently described to promote both glioma tumor growth and genetic instability ${ }^{8}$. The group of IDH mutated, not co-deleted lower-grade gliomas carry a moderate prognosis, while non-IDH1-mutated gliomas carry the worst prognosis ${ }^{2,3}$. These molecular features are less prognostic in primary GBM, which carries a uniformly dismal prognosis ${ }^{2,3}$.

Despite progress in understanding the molecular attributes of glioma, current treatments are sub-optimal and human glioma results in significant morbidity and mortality 9 . Prognosis in gliomas is correlated with the degree of maximal safe resection ${ }^{10,11}$. However, complete resection of gliomas is rarely achieved due to tumor infiltration into normal tissue and/or proximity to critical motor/sensory tracts ${ }^{12}$. Radiation is effective in prolonging survival in GBM and may be beneficial in some grade II/III gliomas ${ }^{13}$. Gliomas generally invade and grow locally; therefore radiation is given focally to involved areas.

Chemotherapy is only minimally effective in the treatment of gliomas. The addition of the alkylating agent temozolomide (TMZ), during and after radiation, prolongs survival in GBM, especially those with promoter methylation of the DNA-damage repair protein $\mathrm{O}^{6}$ methylguanine-DNA methyltransferase $(\mathrm{MGMT})^{9}$. Other cytotoxic agents and regimens have displayed efficacy in certain lower-grade gliomas ${ }^{14}$, but the efficacy of most chemotherapeutic agents is hindered by the difficulty of delivering agents to tumor cells in the brain parenchyma ${ }^{15}$. 
Thus there is an urgent need for the development of efficacious multi-pronged therapies that are tailored to the unique facets of GBM biology.

Recent clinical data has caused a strong interest in the development and evaluation of immunotherapeutic approaches for $\mathrm{GBM}^{16-18}$. Approval of sipuleucel-T (Provenge) for metastatic hormone resistant prostate cancer and ipilimumab (Yervoy) for metastatic melanoma by the FDA has validated the efficacy of immunotherapies in other cancers ${ }^{19}$. In addition, a growing body of evidence has demonstrated the prognostic impact of immune cell infiltrates in the tumor ${ }^{20,21}$.

The CNS has been traditionally considered an immune privileged system. However, a growing body of evidence has challenged this concept lately ${ }^{18,22-25}$. It has been shown that immune cells can cross the blood brain barrier to gain access to the brain parenchyma and can leave the CNS to reach the cervical lymph nodes. Also, the ventricles, meninges, and perivascular spaces lack blood brain barrier $(\mathrm{BBB})$ and their immune-reactivity is not different from that in the periphery ${ }^{22-25}$. Considering that the immune system has access to the brain and that GBM expresses multiple tumor antigens that can be targeted by immunotherapeutic approaches, the development of these therapies has gained considerable interest over the last decade. Immunotherapeutic approaches aim to induce an adaptive immune response that specifically targets and kills GBM cells without affecting normal cells within the brain parenchyma. Although these strategies trigger antitumor immunity ${ }^{26}$, the clinical benefit has been lower than hitherto anticipated. The ability of the immunotherapeutic approach to inhibit the immunosuppressive tumor microenvironment may be crucial to yield tumor regression ${ }^{27,28}$.

\subsection{Mechanisms of immune suppression in GBM}


GBM cells actively contribute to the generation and maintenance of the immunosuppressive microenvironment ${ }^{29,} 30$ (Fig. 1). These cells produce anti-inflammatory cytokines, such as IL-10 and TGF- $\beta$, which inhibit effector T cell responses and APC function, while stimulating regulatory $\mathrm{T}$ cell (Treg) expansion and function ${ }^{31}$. Tregs are also recruited to the tumor microenvironment by the local production of chemokines, such as CCL2, by GBM cells $^{32}$. Besides Tregs, myeloid derived suppressor cells (MDSCs) and tumor associated macrophages (TAMs) also infiltrate the GBM tumor microenvironment, inhibit anti-tumor immune responses, and support tumor progression ${ }^{33,}{ }^{34}$. Modulation of the expression of membrane-bound molecules that interact with tumor infiltrating immune cells is another mechanism that inhibits the adaptive antitumor immune response against GBM. Differential expression of Human Leucocyte Antigen (HLA) molecules has been involved in the immunological escape of GBM. The expression of HLA class I is downregulated in GBM specimens when compared with lower grade astrocytomas, which has been involved in the evasion of cytotoxic T lymphocyte (CTL) responses ${ }^{35}$. Although downregulation of HLA class I reduces the immunogenicity of GBM cells, it could activate NK cell response against the tumor. However, GBM cells overexpress nonclassical HLA class I molecules, such as HLA-G and HLA-E $\mathrm{E}^{36,37}$, which are involved in the inhibition of NK and CTL responses to the allogeneic fetus during pregnancy. Changes in HLA class II expression have also been reported in GBM cells and have been associated with epigenetic changes in the class II transactivator (CIITA) promoter $^{38}$

GBM cells can also directly inhibit $T$ cell function through the expression of negative regulators of T cell function. FasL-expressing GBM cells induce apoptosis of tumor-infiltrating T cells that express Fas ${ }^{39}$. Cytotoxic T-lymphocyte-associated protein 4 (CTLA-4), Programmed 
death-1 (PD-1), Lymphocyte-activation gene 3 (LAG-3), T cell immunoglobulin mucin-3 (TIM3) are negative regulators of the immune system and seem to have a crucial role in GBM immunological escape ${ }^{22}$. While CTLA-4 expression reduces the activation of naive $\mathrm{CD}^{+}$and $\mathrm{CD}^{+} \mathrm{T}$ cells ${ }^{40-42}, \mathrm{PD}-1$ and TIM-3 are markers of $\mathrm{T}$ cell exhaustion in activated lymphocytes ${ }^{43}$. LAG3 is a negative regulator of activated $\mathrm{T}$ and NK cell expansion during chronic inflammation and tumorigenesis ${ }^{44}$. These molecules not only inhibit effector T cell and NK eell activation and function, but they also promote Treg immunossupressive function ${ }^{22}$. Considering that ligands of these proteins are overexpressed in GBM cells, i.e. PD-L1 ${ }^{45}$, galectin- $9^{46}$, they constitute valuable targets to overcome the immunosuppressive nature of GBM and improve the efficacy of immunotherapeutic strategies for GBM.

\section{Immunotherapy approaches}

Immunotherapeutic strategies can be broadly divided into four major classes; (1) immunomodulatory strategies like the ones that target checkpoints using ipilimumab, (2) active immunotherapy such as with cancer vaccines and immune stimulatory gene therapy, (3) passive immunotherapies utilizing antibodies and (4) adoptive strategies such as the ones using chimeric antigen receptor (CAR) T cells.

\subsection{Targeting immunosuppressive checkpoints}

T cells interact with Antigen-Presenting Cells (APCs) and tumor cells, providing signals to regulate immune response through stimulation or inhibition of T-cell activation ${ }^{47}$. These several ligand-receptor interactions are called checkpoint pathways. Checkpoint pathways are non-redundant and can be either co-stimulatory or co-inhibitory. While CD28, TNFRSF4 (OX40), CD40L, CD2 and CD137 enhance immune response, CTLA-4, PD-1, LAG-3, TIM-3 and TIGIT inactivate $\mathrm{T}$ lymphocytes ${ }^{48-53}$. Ligands for these immunosuppressive checkpoints are 
often overexpressed in the GBM microenvironment to inhibit T-cell response against tumor cells, and can be targets for therapies.

CTLA-4 is expressed exclusively by $\mathrm{T}$ cells and inhibits their activation by dephosphorylating the $\mathrm{CD} 3 \zeta$ chain. CD28 and CTLA-4 share the ligands CD80 and CD86, but CTLA-4 binds them with higher affinity ${ }^{54,55}$. Ipilimumab is a fully humanized monoclonal antibody against CTLA-4, approved in 2011 by the FDA and the European Medicines Agency for the treatment of metastatic melanoma which has shown benefits in patients with brain metastasis $^{56-59}$. Extensive preclinical research has shown exciting results with CTLA-4 blockade $^{19}$. Administration of CTLA-4 blocking antibodies improves the survival of animals bearing intracranial SMA-560 tumors ${ }^{60}$, anti-CTLA-4 antibodies in combination with IL-12 also led to the eradication of GL261 gliomas ${ }^{61}$, and the combination of CTLA-4 antibodies with vaccination with GMCSF expressing GBM cells was more effective than either treatment alone $^{62}$. Ipilimumab has demonstrated encouraging results in patients with melanoma and brain metastases as a single agent therapy or in combination with radiotherapy ${ }^{18}$, and a clinical trial evaluating ipilimumab for recurrent and newly diagnosed GBM is currently recruiting patients (NCT02017717).

PD-1 binds to PD-L1 and PD-L2, expressed on surface of tumor cells ${ }^{50,63}$, tumorassociated macrophages ${ }^{33}$, vascular endothelial cells ${ }^{64}$ and some neurons of the tumor microenvironment ${ }^{65}$. Particularly, PD-L1 has been found to have increased expression in GBM patients $^{45}$. In 2014, the FDA approved Pembrolizumab and Nivolumab for metastatic melanoma. Later in 2015, the FDA also approved Nivolumab for non-small-cell lung cancer (NSCLC) ${ }^{66-69}$. Both agents are monoclonal antibodies that inhibit the PD-1 receptor and its interaction with ligands. These antibodies have also shown benefits in patients with other advanced cancers ${ }^{70,71}$. 
The first large phase III trial of Nivolumab and Ipilimumab in GBM patients at different stages of treatment was initiated in 2014 (NCT02017717). Moreover, other PD-1/PD-L1 checkpoint inhibitors are under investigation for solid tumors and hematological cancers (AMP-224, MEDI4736, MPDL3280A, MSB0010418C) $)^{72}$.

TIM-3 and LAG-3 are also being investigated as possible targets for GBM therapy. TIM3 is a glycoprotein with extracellular immunoglobulin and mucin domains that binds Galectin-9 and regulates T-cell exhaustion ${ }^{73}$. It has been shown to be highly expressed in patients with melanoma, NSCLC, lymphoma and other malignancies ${ }^{74}$. In recent investigations it was found that not only was TIM-3 expression significantly increased in peripheral blood CD4 ${ }^{+}$and $\mathrm{CD} 8^{+}$ $\mathrm{T}$ cells of glioma patients compared with healthy controls, but that the expression of galectin-9 in tumor tissues was associated with TIM-3 expression on Tumor Infiltrating Lymphocytes (TILs) and the WHO grade of glioma ${ }^{46,75}$. Some studies show that combination therapy with anti-PD-1, anti-TIM-3 and focal radiation results in regression of murine gliomas, concluding that the addition of a second checkpoint-blocking antibody could achieve additive or synergistic antitumor effects ${ }^{76}$. Checkpoint blockade could also prove a useful adjuvant when combined with other therapeutic strategies. Indoleamine 2, 3 dioxygenase 1 (IDO) is a tryptophan catabolic enzyme induced in GBM patients ${ }^{77}$. IDO expression by brain tumor cells is critically important in the immunosuppressive tumor microenvironment because it modulates Treg activation, expansion and recruitment ${ }^{78}$. Recent research shows that blockade of CTLA-4 and PD-L1 in combination with IDO inhibition using 1-methyltryptophan (1-MT) in murine glioblastoma models results in a highly effective survival advantage and a significantly decreased level of Tregs, in comparison with the mono or dual therapies ${ }^{79}$. 
LAG-3 is a CD4 homolog that binds MHC Class $\mathrm{II}^{80}$ and seems to act synergistically with PD-L1 to control the expansion of already activated T-cells. It was found to be highly expressed on TILs from patients with melanoma, colorectal cancer or fibrosarcoma ${ }^{81}$. Currently, there is an ongoing phase I trial that studies the treatment with anti-LAG-3 mAb alone on in combination with Nivolumab in patients with recurrent glioblastoma (NCT02658981).

Of note, inhibition of immunological checkpoints not only improves the efficacy of immune-stimulant strategies, but can also be used in combination with-conventional therapies, such as chemotherapy and radiotherapy ${ }^{16}$. Checkpoint inhibitors have also been shown to enhance the efficacy of anti-glioma stem cell treatments ${ }^{82}$.

\subsection{Gene therapy}

Gene therapy initially developed to restore the function of defective or absent genes, and has gained popularity for the treatment of glioblastoma, due in part to the failure of other treatment options and to the successful design of many vectors able to safely deliver therapeutic genes into the tumor, such as viruses (adeno- and adeno-associated, retroviruses, herpes simplex virus, measles, reovirus, poliovirus), stem cells (neural, mesenchymal or embryonic), liposomes and nanoparticles ${ }^{17,83}$. Current gene therapeutic approaches for glioma can be classified in four categories: suicide gene therapy, oncolytic virotherapy, tumor suppressor gene therapy and immuno-stimulatory therapy ${ }^{84}$. Viral mediated gene therapies can induce immunogenic cell death of malignant cells ${ }^{85}$ and release of damage associated molecular patterns like HMGB1 ${ }^{86,87}$, leading to improved antigen presentation and enhanced anti-tumor immune response.

\subsubsection{Suicide gene therapy}


Suicide gene therapy relies on the targeted administration of an enzyme, most commonly the viral gene thymidine kinase (TK), into dividing tumor cells. Upon administration of an inactive prodrug, for example ganciclovir (GCV), TK will convert it into a toxic metabolite, resulting in tumor cell apoptosis ${ }^{88-90}$. This strategy has shown success in numerous preclinical trials of glioma and has also been tested in several phase I and II clinical trials, which demonstrated the safety for this gene therapeutic approach ${ }^{91,92}$. However, a large randomized phase III trial of HSV-TK/GCV in combination with surgery and radiation failed to show improved survival in newly diagnosed $\mathrm{GBM}^{93}$.

To improve upon this treatment, our group has developed a therapeutic strategy using adenovirus-mediated delivery of Flt3L, a cytokine which induces the generation and stimulates the migration of dendritic cells (DCs) ${ }^{94}$. In several preclinical studies we have shown that AdFlt3L in combination with AdTK/GCV induced prolonged survival of tumor-bearing animals, and that this was associated with increased recruitment of DCs into the tumor, generation of tumor specific T-cell responses and of long-term immunological memory, an effect dependent on the TLR2 activation by HMGB1 released by the dying tumor cells ${ }^{87,95-99}$. A phase I clinical trial using this gene therapeutic approach is currently underway (NCT01811992, https://clinicaltrials.gov/show/NCT01811992).

\subsubsection{Oncolytic viral therapy}

Oncolytic viral (OV) therapy exploits the ability of conditionally replicative viral vectors to selectively divide within tumor cells, induce their lysis, and amplify engineered therapeutic genes within the tumor environment. In addition to the direct oncolytic activity, OVs are also very effective at inducing immune responses to themselves and to the infected tumor cells ${ }^{85}$. 
Oncolytic viruses tested in clinical trials for glioma include: oncolytic Herpes Simplex Virus $(\mathrm{oHSV})^{100,101}$, conditionally replicating adenoviruses (CRAds), oncolytic measles ${ }^{102}$ and reovirus vectors $^{103}$. These vectors have shown safety when administered in phase I clinical trials and show improvement over non-replicating viruses in terms of efficiency of transduction of the therapeutic gene. A drawback however is represented by the vector-induced immune response. Further modifying these vectors can reduce their antigenic properties, and efforts have been made to increase selectivity of the vectors, using glioma specific and radiotherapy inducible promoters, like survivin ${ }^{104,}{ }^{105}$. Two CRAd's have been evaluated in clinical trials for glioma: ONYX-015, engineered to replicate in p53 deficient tumor cells, has been demonstrated to be safe when administered intracranially, but shows no clinical benefit ${ }^{106,107}$, and Ad5Delta24, further modified into Ad5Delta24-RGD and DNX2401 ${ }^{108}$ to increase its targeting to tumor cells, is currently tested in several Phase I/II trials: NCT01582516- phase I/II trial testing the convection enhanced delivery of Delta-24rgd in patients with recurrent GBM, NCT02197169phase I unicentric trial (Target-I) testing DNX2401 expressing IFN- $\gamma$ in recurrent glioblastoma or gliosarcoma, and NCT01956734, a phase I trial testing DNX2401 in combination with temozolomide.

\subsubsection{Immunomodulatory gene therapy}

Immunomodulatory gene therapy is designed to create a tumor environment optimized for the induction of an effective anti-tumor immune response. This has been tried with targeted delivery of cytokines into the tumor microenvironment to achieve higher local concentrations of immuno-stimulatory molecules, such as IL-2, IL-4, IL-12, IFN- $\gamma$ and IFN- $\beta$, without generating systemic side effects. 
IL-2, known to induce proliferation of all immune cells and to enhance production of other immunostimulatory cytokines has first been tested in glioma patients in 1986 when recombinant IL-2 and autologous lymphokine activated killer cells (LAK cells) were directly injected into the tumor cavity, demonstrating safety and in vitro tumor specific killing by LAKs $^{109}$. Systemic administration of IL-2 has shown to be poorly tolerated ${ }^{110}$. In a phase I trial, combination of suicide gene therapy and IL-2, obtained through the administration of retroviral producing cells expressing IL-2 and HSV-TK resulted in minimal side effects and partial response, evidenced by MRI, in 2 of 12 patients $^{111}$.

IL-4 stimulates proliferation of lymphocytes acting synergistically with IL-2 and also induces DC maturation and production of IL-12. In a rat glioma model, subcutaneous vaccines with 9L cells transduced with HSV expressing TK, IL-4, or TK + IL-4 inhibited subcutaneous tumor growth and increased survival upon challenge with intracranial 9L tumors ${ }^{112}$. This was correlated with increased production of IFN- $\chi$ in the splenocytes of treated animals challenged with irradiated tumor cells. This strategy was tested in a phase I trial ${ }^{113}$, results of which have not been published.

The type /interferon gene IFN- $\beta$ has been widely tested in treatments of several cancers, showing direct antiproliferative effect, and in glioma enhances sensitivity for TMZ treatment ${ }^{114}$, ${ }^{115}$. In Japan, a phase I clinical trial with liposomal delivery of IFN- $\beta$ showed minimal toxicity and clinical response with more than $50 \%$ reduction of the tumor in 2 out of 5 patients ${ }^{116}$. This study was followed by another phase I trial using administration of Ad-hIFN $\beta$ into the tumor cavity and surrounding tumor area post resection, demonstrating safety and induction of tumor cell apoptosis ${ }^{117}$. 


\subsection{Active immunotherapy}

Cancer vaccines aim at stimulating adaptive immune responses that target tumor-specific antigens. Strategies utilized include delivery of tumor-associated antigens, administration of tumor antigen loaded DCs and tumor cell vaccines.

\subsubsection{Peptide vaccination: tumor associated antigens and shared neoantigens}

Successful immunotherapies rely on the targeting of glioma-specific antigens to selectively kill tumor cells, without inducing autoimmune reactions. To date, numerous glioma associated antigens (GAA) have been identified (Table 2), and targeted therapies have been developed and tested in recently completed and ongoing clinical trials. Several known tumorassociated antigens such as HER-2, TRP-2, gp100, MAGE-1, IL-13 $\alpha 2$ and AIM-2 are being targeted in $\mathrm{GBM}^{16-18}$. Additionally, new immuno-therapeutic strategies use neoantigens to specifically target tumor cells. Neoantigens represent antigenic molecules, absent from normal tissues, which result from tumor specific DNA somatic mutations present within protein-coding regions; commonly occurring mutations, shared by many tumors, are attractive targets for therapy $^{118,119}$. The most extensively studied target is EGFR variant III ${ }^{16-18}$. EGFRvIII is a mutant form of the EGFR gene, found in $20-30 \%$ of GBM patients, expressing a truncated, constitutively active form of the receptor, causing increased proliferation and survival advantage of GBM tumor cells ${ }^{120}$. Evaluation of Rindopepimut/CDX-110 (14 amino acid peptide conjugated to KLH) in 18 patients with EGFRvIII mutation in combination with standard radiotherapy and chemotherapy showed a median survival of 26 months. At recurrence $82 \%$ of the tumors lost EGFRvIII expression suggesting treatment induced immunoediting. Currently a phase III (NCT01480479) multi-center trial is looking at the efficacy of CDX-110, GMCSF, 
TMZ and keyhole limpet hemocyanin (KLH) for the treatment of adult patients with EGFRvIII positive gliomas and a phase II study is evaluating the combination of rindopepimut, GMCSF and bevacizumab in relapsed EGFRvIII positive gliomas (NCT01498328).

Mutations of IDH1 and IDH2 have been found in more than $80 \%$ of WHO grade II/III astrocytomas, oligodendrogliomas and oligoastrocytomas ${ }^{5}$. For IDH1, the most common genetic alteration is represented by a single nucleotide substitution: $\mathrm{R} 132 \mathrm{H}$, encompassing more than $70 \%$ of all IDH mutations. To test if this neoantigen is amenable for immunotherapeutic targeting, Schumacher et al. ${ }^{121}$ generated a peptide library encompassing this mutation and tested its ability to bind MHC-I and MHC-II. This study demonstrates that several 15 mer peptides bound to the human MHC-II allele HLA-DRB1*0101 and that MHC-II humanized mice immunized with one of these peptides developed robust IFN $\gamma$ T-cell responses resulting in Th1 CD4 specific responses with generation of mutation-specific anti-IDH1 antibodies detectable in the serum. Furthermore, specific IFN $\gamma$ producing $\mathrm{T}$ cells were isolated from the serum of patients harboring IDH1 (R132H)-mutated gliomas but not from patients with wild type IDH gliomas. Also tumor growth was reduced in MHC-II humanized mice immunized with the IDH1 (R132H) peptide vaccine, effect dependent on CD4+ cells. Notably, immunization with the mutant peptide induced immuno-editing of the IDH1 (R132H) tumors, which resisted vaccination and showed marked decrease in IDH1 (R132H) expression. This study highlights the importance of CD4+ T-cell-mediated anti-tumor immune response in the absence of an MHCclass-I-restricted CD8 $+\mathrm{T}$ cell response and the potential therapeutic success when targeting this neoantigen with immunotherapy. Currently, an open clinical trial (RESIST, led by Dr. Vlahovicat at Duke University, NCT02193347) is testing the use of the IDH1 Peptide Vaccine (PEPIDH1M) administered with GM-CSF and tetanus toxoid preconditioning of the vaccine site 
in adult patients with recurrent grade II glioma positive for IDH1R132H. Another Phase 1 clinical trial (NOA-16) is testing an IDH1 Peptide Vaccine in patients with IDH1R132H mutant grade II and IV tumors with ATRX loss and without 1p/19q codeletion.

Diffuse intrinsic pontine glioma (DIPG) is often associated (70\%) with missense mutation of the lysine in the histone H3.3 K27M, with the mutation also present in $30 \%$ of adult GBM patients. A recent report tested whether this mutation can serve as neoantigen for immunotherapy and if it can initiate a specific CTL response. Preliminary results show that out of 4 peptides generated by a peptide-MHC binding algorithm and a proteosomal cleavage site prediction system, one was able to induce specific CTL responses which specifically lysed HLA$\mathrm{A}^{+}$DIPG cell lines harboring the mutation ${ }^{122}$. If proven safe and effective this therapeutic strategy will bring great hope for children with DIPG.

One potential drawback of single peptide vaccination is immuno-editing; the concept of immuno-editing, describing the crosstalk between the immune system and cancer, has developed over the last century from the idea of immune surveillance, which posits that the immune system is continuously monitoring and capable of eliminating cells displaying neoplastic mutations ${ }^{123-}$ 125. As cancer still develops in immuno-competent organisms, the immune surveillance is eventually overcome due to the aggressive growth and invasion of cancers and to immunosuppressive mechanisms induced by malignancy ${ }^{126}$. Immuno-editing represents a major obstacle for the success of immunotherapies for glioma. Deciphering mechanisms of immuno-editing will lead to an increased understanding of glioma pathogenesis and progression and to the design of more successful immunotherapies for this disease.

As discussed above, an illustrative example of glioma immuno-editing following targeted 
immune therapy is represented by the recently completed Phase II multicenter study (ACTIVATE, ACTII), which used the CDX-110 vaccine (Rindopepimut) concurrent with temozolomide in patients with newly diagnosed EGFRvIII-positive GBM ${ }^{127}$. The ACTII trial demonstrated that OS was positively correlated with the development of specific antibody responses against EGFRvIII (identified in 6 of 14 patients), and that remarkably, at recurrence $82 \%$ of patients had lost EGFRvIII expression ${ }^{127,}{ }^{128}$. Immuno-editing was also demonstrated in a subsequent Phase II multicenter single-arm trial (ACTIII) using the same therapeutic approach, showing decrease of EGFRvIII immunoreactivity in 67\% (4 of 6 patients), and an OS of 21.8 months ${ }^{129}$. A Phase III Study (ACT IV) of Rindopepimut, GM-CSF, TMZ and KLH for patients with newly diagnosed EGFRvIII positive gliomablastoma will likely be discontinued as the interim analysis showed that the treatment is unlikely to meet statistically significant primary OS endpoint in patients with minimal residual disease ${ }^{130}$

To reduce the risk of immuno-editing, immune tolerance and disease recurrence following single peptide vaccinations, many studies are investigating the production of effective combinations of several GAA. A recently completed study has tested the intradermal administration of a combination of three peptides: EphA2, IL-13R $\alpha 2$ and survivin together with tetanus toxoid and poly [I:C] as adjuvants in pediatric brain stem and high grade gliomas (NCT01130077). Results showed that the vaccine was well tolerated, induced the development of specific GAA immune responses, and led to favorable clinical outcome, particularly in patients manifesting temporary pseudo-progression, indicative of immune cell infiltration within the tumors causing edema ${ }^{131}$. Other ongoing clinical trials are testing a combination of the immunogenic peptides IL13R 2 2, EphA2 and Survivin (SL-701 vaccine in combination with bevacizumab, NCT02078648) in patients with newly diagnosed GBM. The ICT-107 vaccine is 
an autologous DC vaccine pulsed with six peptides (HER2, TRP-2, gp100, MAGE-1, IL13R $\alpha 2$ and AIM-2). In the initial phase I trial this treatment induced a response in $33 \%$ of the 21 patients enrolled with a median OS of 38.4 months ${ }^{132}$. This vaccine is currently being tested in a randomized, two-arm, phase III study with ICT-107 or placebo control in combination with the SOC (NCT02546102). Ongoing clinical trials are testing a proprietary combination of 11 HLAA2 restricted tumor-associated peptides IMA950 alone (NCT020278648) or in combination with GMCSF (NCT01222221) or TLR3 agonist, Poly ICLC (NCT01920191).

\subsubsection{Peptide vaccination: patient-specific neoantigens}

Identification of patient-specific neoantigens has been made possible by the advent of next-generation DNA and RNA deep sequencing technology, the development of prediction algorithms, MHC multimer based screens ${ }^{133}$, and high throughput sequencing of antigen-specific receptors of whole lymphocyte populations (TCRseq, BCRseq) capable of identifying patientspecific combinations of immunogenic neo-antigens. That specific $\mathrm{T}$ cell reactivity can be induced by neoantigens identified through cancer exome sequencing has been demonstrated in melanoma patients ${ }^{134,135}$, results which prompted the development of clinical trials to target patient-specific neoantigens with immune therapy in several cancers. This strategy has been adopted by the European Glioma Actively Personalized Vaccine (GAPVAC) Consortium in a phase I clinical trial (NCT02149225) testing personalized peptide vaccines in combination with Poly-ICLC and GM-CSF in newly diagnosed glioblastoma. A phase-I clinical trial led by Dr. Reardon at the Dana Farber Cancer Institute is testing the safety and efficacy of neoantigen based vaccines in combination with radiation in MGMT-unmethylated newly-diagnosed GBM (NCT02287428).

An avenue of increased interest in the management of cancers is represented by the 
targeting of neoantigens induced by radiation therapy ${ }^{136,}{ }^{137}$. Ionizing radiation induces DNA strand breaks, which will kill rapidly dividing cells and induce immunogenic cell death, generating damage associated molecular patterns, like HMGB1 ${ }^{138}$ and induce phenotypic changes in normal and malignant cells. It has been shown in preclinical models of glioma that radiation therapy induces the expression of novel targets such as integrins $\alpha v \beta 3$ and matrix metalloproteinases MMP2 and MMP9, which can promote glioma progression ${ }^{139}$, however when combined with immune checkpoint blockade using anti PD-1 antibodies, radiation therapy induces long-term survival in glioma bearing animals ${ }^{140}$. In other cancer models it has also been shown that radiation induces various cell surface receptors on tumor cells (MHC-I, ICAM-1, Fas), and that radiotherapy augmented tumor cell killing by antigen specific $\mathrm{T}$ cells ${ }^{136}$. Combining next generation sequencing with radiotherapy to identify immunogenic mutations ${ }^{141}$ and designing therapeutic antigenic peptides to be used as agents in combinatorial approaches with radiation and immune checkpoint blockade are attractive strategies to pursue further for the treatment of glioblastoma.

A recent study from our lab has shown that loss of ATRX increases genetic instability. Furthermore, analysis of genome-wide data for human gliomas showed that ATRX mutation is associated with increased mutation rate at the single-nucleotide variant (SNV) level ${ }^{8}$. Tumors with ATRX loss could therefore potentially be more immunogeneic due to the generation of neoepitopes or neoantigens. As pointed out by Schumacher et al, such neoantigens are crucial to tumor rejection because the $\mathrm{T}$ cell repertoire against these antigens is not affected by central tolerance ${ }^{118}$.

\subsubsection{Vaccination}


DCs are the most efficient APCs that can activate CD4, CD8, NK and NKT cells ${ }^{17}$. Factors that can modulate the efficacy of DC vaccination strategies include methods of DC differentiation, loading with tumor antigens, route of administration, and adjuvants used (Fig 2 and Table 3) ${ }^{17}$. The most advanced current clinical trial using an autologous DC vaccineDCVax-L is in Phase III (NCT00045968). While the vaccine was shown to be safe, limited clinical benefit was observed. Combination of autologous DC vaccine with Imiquimod or Poly ICLC showed increased OS in patients with mesenchymal gene signature ${ }^{142}$. Increased OS was also seen in $33 \%$ of the patients treated with DC vaccine pulsed with six GAA peptides ${ }^{132}$. Treatment of 22 patients with recurrent GBM with $\alpha$-type 1 polarized DCs pulsed with EphA2, IL13R $\alpha 2$, YKL-40 and gp100 combined with poly ICLC showed the induction of a positive immune response in $58 \%$ of the patients ${ }^{143}$. An interesting approach using DC vaccination was utilized to target glioma stem cells (GSCs). A recently completed phase I/II trial (NCT00846456) using DCs transfected with autologous GSC MRNA demonstrated significantly longer PFS and OS than the controls. Like EGFRvIH peptide vaccines, DC vaccines pulsed with CDX-110 showed safety and efficacy in eliciting an anti-tumor immune response and improved survival in GBM patients that expressed the variant ${ }^{128}$. Results from a randomized and blinded clinical trial by the Sampson group have demonstrated that pre-conditioning the vaccine site with antigens such as tetanus/diphtheria toxoid can significantly improve the efficacy of tumor-antigen-specific $\mathrm{DCs}^{144}$. Patients given tetanus toxoid had enhanced DC migration bilaterally and significantly improved survival ${ }^{144}$.

\subsubsection{Tumor cell vaccination}

Encouraging results were seen in a prospective Phase I/II clinical trial using temozolomide, radiotherapy and autologous formalin fixed tumor cell vaccine in 24 patients with newly 
diagnosed $\mathrm{GBM}^{145}$. A recent phase II clinical trial of adult recurrent GBM in which vaccines were made by isolating tumor gp96 complexes from autologous-resected tumors (HSPPC-96) demonstrated the safety and OS of 42.6 weeks ${ }^{146}$. A randomized phase II trial will compare the efficacy of HSPPC-96 vaccine with or without bevacizumab in recurrent resectable GBMs (NCT01814813).

\subsubsection{Immune stimulatory adjuvants}

Immune adjuvants can enhance vaccine associated anti-tumor immunity through mechanisms such as antigen clustering, maintaining an antigen depot, stimulating innate immunity, promoting DC maturation, and blocking Treg induced suppression ${ }^{16-18}$. Compounds most commonly evaluated as adjuvants are poly I:C, CpG oligonucleotides, and Imiquimod that activate TLR3, TLR9 and TLR7 respectively ${ }^{16-18}$. TLRs are pathogen associated molecular pattern receptors that when activated increase the production of immune-stimulatory cytokines and costimulatory molecule expression on $\mathrm{APCs}^{147}$. In a prospective phase II clinical trial of pediatric glioma, treatment with poly ICLC was well tolerated by children. 5 out of 10 children showed long-term stable disease ${ }^{148}$. Another phase II trial testing the combination of poly ICLC with radiotherapy and TMZ concluded that poly ICLC administration may improve the efficacy of radiotherapy and TMZ treatment with no added adverse effects ${ }^{149}$. While CpG-ODN showed promise in many preclinical and phase I clinical studies, intratumoral administration of $\mathrm{CpG}$ ODN as a single treatment modality showed little benefit in a phase II clinical study with patients with recurrent $\mathrm{GBM}^{150}$. Besides TLR agonists, other immune stimulatory adjuvants have also been tested. Administration of tetanus toxoid was shown to improve the efficacy of DC vaccination in GBM patients and to prolong their survival ${ }^{144}$. Mitchell et al. reported that tetanus toxoid preconditioning in vaccination site in a mouse glioma model enhanced DC migration and 
suppressed tumor growth in a CCL3 dependent fashion ${ }^{144}$. KLH is being tested in active vaccination studies for GBM patients. GMCSF has also been used to promote vaccine immunogenicity by enhancing DC maturation ${ }^{151}$.

\subsection{Passive immunotherapy: antibodies}

Monoclonal antibody therapy results in tumor cell death through a variety of immune and non-immune mediated mechanisms ${ }^{152}$. Ideally the expression of the antigen recognized by the antibody would be restricted to the tumor cells, so as to minimize injury to normal tissues. GBMs are highly vascular tumors that produce large amounts of VEGF. Currently, the most prominent VEGF targeting drug is bevacizumab (BEV), a recombinant humanized monoclonal antibody that binds to human VEGF-A. Several phase II trials have tested the efficacy of anti-VEGF therapies either alone or in combination with irinotecan, etoposide, nitrosourea, or other agents ${ }^{153}$. While BEV proved to be a safe and feasible treatment option, the initially reported promising response rates might partly be attributed to imaging limitations resulting in an apparent but debatable reduction in the contrast-enhancing tumor volume [31, 32]. Recent prospective phase III trials (AVAglio \& RTOG 0825) were designed to prove the efficacy of TMZ based radio chemotherapy in combination with BEV as first-line therapy for GBM. While the RTOG 0825 trial failed to show significant benefits in terms of progression free (PFS) and overall survival (OS), the AVAglio study demonstrated a significant prolongation of PFS by 4.4 months in the BEV arm. However, this PFS benefit did not translate into an improvement in $\mathrm{OS}^{153}$. Epidermal growth factor receptor gene mutation is a frequent finding in GBM with EGFR

yariant VIII being the most common one. Combination therapy of anti-EGFRvIII antibody, cetuximab in combination with bevacizumab/irinotecan was not found to be superior than bevacizumab/irinotecan alone. Intra-arterial infusion of cetuximab alone or in combination with 
BEV is currently being tested ${ }^{154}$ (NCT01884740 and NCT01238237). Another antibody against EGFR, nimotuzumab, in combination with radiation and chemotherapy in patients with diffuse intrinsic pontine gliomas has shown an increased median OS of 15 months when compared to 9.4 months for nimotuzumab and radiation alone ${ }^{155}$. A randomised, open label phase III trial was conducted to evaluate efficacy of nimotuzumab added to standard therapy for newly diagnosed glioblastoma. No statistically significant increase in overall survival was observed by the addition of nimotuzumab ${ }^{156}$. ABT-414 is an antibody-drug conjugate that delivers Monomethyl Auristatin F or MMAF to cells with active EGFR or mutant EGERvIII Interim results from a phase I clinical trial testing ABT 414 as a monotherapy, in combination with chemotherapy and in combination with radiation and chemotherapy showed objective responses in 4 out of 12 patients, including 2 that showed complete response (NCT02573324).

\subsection{Adoptive immunotherapy: autologous $T$ cell transfer and CAR $T$ cells}

Adoptive $\mathrm{T}$ cell transfer involves directly transferring $\mathrm{T}$ cells with high avidity against the tumor antigens to the host to generate anti-tumor immunity ${ }^{152}$. Rosenberg et al pioneered the technique in a subset of melanoma patients by expanding TILs obtained from resected melanoma tumors ${ }^{157}$. The technique however was limited by the availability of tumor-specific lymphocytes. To overcome this limitation, the same group developed patient $\mathrm{T}$ cells genetically modified to express a T cell receptor that recognized melanoma antigen MART-1, resulting in tumor regression ${ }^{158}$. Early approaches utilizing adoptive transfer for glioma involved administration of T cells isolated from dLNs following s.c. injection of irradiated tumor cells with GMCSF or ex vivo expansion of $\mathrm{T}$ cells induced by culture with tumor cells ${ }^{152}$. In a phase I clinical trial in patients with recurrent GBM and cytomegalovirus positive serology, adoptive transfer of autologous CMV-peptide expanded T cells resulted in a PFS of 243 days in 4 out of 10 
patients ${ }^{159}$. Adoptive $\mathrm{T}$ cell transfers are restricted by the need to match the HLA type, and next generation $\mathrm{T}$ cell transfer strategies use CAR $\mathrm{T}$ cells. Chimeric antigen receptor $\mathrm{T}$ cells, or CAR $\mathrm{T}$ cells, are engineered to target a specific antigen by combining the recognition specificity of an antibody with $\mathrm{T}$ cell signaling through the $\mathrm{CD} 3 \zeta$ chain or FCERI $\gamma^{160}$. A serious concern with the use of this approach is the damage that can occur to normal tissues if the antigen expression is not tumor specific. Thus it is essential to select targets that show tumor restricted expression. Using CARs as a therapeutic strategy in brain tumors was first tested by the Jensen group, who showed that intratumoral delivery of IL-13 zetakine CAR eliminated orthotopic human glioma tumors in immune compromised mice ${ }^{161}$. The clinical trial testing the safety and feasibility of this therapy in patients with recurrent GBM has shown minimal side effects, and 2 out of 3 patients who received repeated intracranial infusions of LL-13 zetakine+ CTLs showed transient anti-glioma immune responses ${ }^{162}$. HER2-specific CAR $\mathrm{T}$ cells have been shown to generate a HER2-dependent antitumor response with increased production of IFN- $\gamma$ and IL-2, resulting in tumor regression in a xenograft mouse GBM model ${ }^{163}$. A phase I trial will test the safety and efficacy of using HER2-specific CARs in patients with recurrent GBM (NCT02442297). The Rosenberg group at NCI (NCT01454596) and the University of Pennsylvania/Novartis (NCT02209376) are also currently recruiting participants to test the safety and feasibility of administering $\mathrm{T}$ cells expressing anti-EGFRvIII CAR to patients with gliomas expressing EGFRvIII. The role of engineered T cell therapy may be expanded in the future to include gene transfer mediating extended survival, enhanced tumor penetration, or resistance to immunosuppression ${ }^{164}$.

\section{Predictive biomarkers for immunotherapy}


Significant advances have been made in genetic and molecular characterization of tumors, allowing for the identification of predictive biomarkers for glioma immunotherapy. As mentioned above, clinical trials of EGFRvIII CAR T cell therapy (NCT02209376) and EGFR peptide vaccination (NCT00458601, NCT01480479) used glioma EGFRvIII expression as a precondition for enrollment, limiting the potential for adverse events in those who were not likely to experience therapeutic benefit ${ }^{165}$. Similarly, IL-13R $\alpha 2$ expression was used as a precondition for enrollment in a clinical trial of IL-13R $\alpha 2$ CAR T cells (NCT02208362). Other biomarkers such as IDH1/2 mutation, 1p/10q deletion, MGMT methylation, ATRX loss, and H3.3 K27M mutation ${ }^{166}$ are prognostically useful, and their ability to predict therapeutic efficacy of a particular immunotherapy remains open for exploration ${ }^{167}$. Large scale clustering of several biomarkers into neural, proneural, classical, and mesenchymal subtypes corresponds with differences in treatment efficacy of chemotherapy and radiotherapy, and holds significant potential for informing efficacy of immunotherapy ${ }^{168}$. In a Phase I trial testing autologous tumor lysate-pulsed DC vaccination (NCT01204684), the study population was stratified according to the genetic expression signature of tumor cells (mesenchymal, proneural and proliferative), and patients with mesenchymal signatures, the worst prognostic subtype, had significantly extended survival compared to a historical control cohort with the same signature, whereas no survival difference was observed in those with a proneural gene expression signature ${ }^{142}$. Moreover, the mesenchymal subtype showed higher numbers of CD3+ and CD8+ TILs compared with other subtypes, suggesting that gene expression profile can be used as a biomarker for choosing an efficacious immunotherapy.

Alternatively, biomarkers which are not tumor-associated may also hold significant predictive value. Hsu et al. analyzed sequence similarity of the T cell receptor (TCR) $\beta$ chain 
gene between $\mathrm{T}$ cells in the tumor and those in the peripheral blood. They showed that two patients with the highest TCR sequence similarity between tumor and blood before treatment showed the longest survival among 5 patients who were treated with DC vaccine ${ }^{169}$. HLA type may be an important predictive biomarker for peptide vaccines. The EphA2, IL-13Ra2, and survivin peptide vaccine was optimized to bind HLA-A2 most efficiently; thus the clinical trial prescreened for HLA-A2 expression prior to enrollment (NCT01130077). Humoral biomarkers may also aid in monitoring biological effects of immunotherapy. Recently, Everson et al. tested the association of phospho-STAT signaling and patient survival after DC vaccine treatment ${ }^{170}$. An increased per cell phosphorylation of STAT-5 in cytotoxic T-cells following IL-2 stimulation was associated with extended survival $(\log \operatorname{rank} p=0.0015)$. Patients who survived longer than two years had a significantly greater phosphorylated STAT-5 ratio $(p=0.015)$.

\section{Expert opinion}

GBMs remain one of the most difficult to treat human cancers. In spite of optimal standard of care, delivered in the most complex and advanced medical institutions, its prognosis has remained dismal, with a median survival of $\sim 12-18$ months post diagnosis ${ }^{9,16,18}$. This is thought to be due to the fact that GBMs are usually diagnosed at late stages of the disease; the blood brain barrier precludes the effective action of chemotherapeutic agents, there is a paucity of antigen presenting cells (APCs) within the central nervous system, and GBM is highly immunosuppressive $\mathrm{e}^{30,31,33,39,45,49,171}$. The tumor microenvironment in GBMs is composed mainly of immunosuppressive cells, i.e., regulatory $\mathrm{T}$ cells (Tregs), tumor associated macrophages (TAMs) and myeloid derived suppressor cells (MDCSs). These cells exhibit immunosuppressive effects, which inhibit anti-tumor specific cytotoxic $\mathrm{T}$ cells functions, ultimately leading to decreased efficacy of immunotherapeutic approaches. In addition, GBMs 
are highly heterogeneous, with tumor cells acquiring new mutations after treatment, leading to therapy resistant disease $\mathrm{e}^{172,173}$.

In GBM, tumor infiltrating $T$ cells and Tregs exhibit high levels of the immunosuppressive receptor, CTLA4. CTLA4 binds with high affinity to CD80 and CD86, which are present on APCs, therefore inhibiting their binding to the T cells' immune stimulatory receptor $\mathrm{CD} 28^{22,43,72}$. This powerful immunosuppressive mechanism can be overcome by the use of antibodies which block CTLA $4^{22,43,72}$. Another powerful immunosuppressive mechanism is mediated by PD1-PDL1/PDL2 interactions, which occur during the effector phase of T cells functions leading to apoptosis of cytotoxic $\mathrm{T}$ cells $\mathrm{s}^{22,43,72}$. Thus, immune checkpoint blockade has become a very attractive therapeutic target to be used in combination with other chemotherapeutic strategies, radiation, and/or immunotherapies ${ }^{22,}$ 72, 174. Although these approaches are yielding very promising results in GBM preclinical models $\mathrm{s}^{62,76}$ and clinically for the treatment of immunogenic cancers, such as melanoma ${ }^{56,66}$, no data is available yet in relation to their clinical efficacy in GBM. The clinical trial approach that we developed in our laboratory, which entails using a combination of a conditional cytotoxic gene therapy approach ${ }^{88,89}$ together with an immune stimulatory approach to attract APCs to the tumor microenvironment ${ }^{87,95-99}$, has proven to be highly efficacious in several rat and mouse syngeneic, intracranial GBM models and is currently being tested in the clinic (https://clinicaltrials.gov/show/NCT01811992). In summary, taking into account the formidable challenges posed by GBM, we hypothesize that in order to elicit therapeutic benefit, it will be necessary to use combination therapies. These should include, surgery (aiming to perform aggressive resections when clinically possible) chemotherapy, radiation, and immune stimulatory approaches. These could include vaccination strategies, intra-tumor gene therapy strategies, oncolytic virotherapy, and immune checkpoint 
blockade. Although we have a long way ahead, we believe that the basic science discoveries related to how the immune system works in GBM, coupled with well-designed clinical trials, will enable the scientific/medical community to make inroads into developing novel combination therapies that will elicit improved median survival and better prognosis for this devastating cancer.

Funding: This work was supported by National Institutes of Health/National Institute of Neurological Disorders \& Stroke (NIH/NINDS) Grants R01-NS094804, R01-NS074387, R21NS091555, and R37-NS094804 to M.G.C.; NIH/NINDS Grants R01-NS076991, R01NS082311, R21-NS084275, and R01-096756 to P.R.L.; Leah's Happy Hearts, University of Michigan Comprehensive Cancer Center, Chad Tough Foundation, and The Phase One Foundation to both M.G.C. and P.R.L.; the Department of Neurosurgery, University of Michigan School of Medicine; the Michigan Institute for Clinical and Health Research, NIH 2UL1TR000433; University of Michigan Cancer Biology Training Grant, NIH/NCI (National Cancer Institute) T32-CA009676; University of Michigan Training in Clinical and Basic Neuroscience, NIH/NINDS T32-NS007222; and the University of Michigan Medical Scientist Training Program, NIH/NIGMS (National Institute of General Medicine Sciences) T32-GM007863.

Declaration of interest: The authors have no relevant affiliations or financial involvement with any organization or entity with a financial interest in or financial conflict with the subject matter or materials discussed in the manuscript. This includes employment, consultancies, honoraria, stock ownership or options, expert testimony, grants or patents received or pending, or royalties.

\section{References}


1. Louis DN, Ohgaki H, Wiestler OD, et al. The 2007 WHO classification of tumours of the central nervous system. Acta neuropathologica 2007 Aug;114(2):97-109.

2. Eckel-Passow JE, Lachance DH, Molinaro AM, et al. Glioma Groups Based on 1p/19q, IDH, and TERT Promoter Mutations in Tumors. The New England journal of medicine 2015 Jun 25;372(26):2499508.

3. Suzuki H, Aoki K, Chiba K, et al. Mutational landscape and clonal architecture in grade II and III gliomas. Nature genetics 2015 May;47(5):458-68.

4. Paulus W. Pathology, molecular mechanisms and markers of gliomas: new insight and new challenges. Acta neuropathologica 2015 Jun;129(6):773.

5. Yan H, Parsons DW, Jin G, et al. IDH1 and IDH2 mutations in gliomas. The New England journal of medicine 2009 Feb 19;360(8):765-73.

6. Jiao Y, Killela PJ, Reitman ZJ, et al. Frequent ATRX, CIC, FUBP1 and IDH1 mutations refine the classification of malignant gliomas. Oncotarget $2012 \mathrm{Jul} ; 3(7): 709-22$.

7. Chamberlain MC, Born D. Prognostic significance of relative 1p/19q codeletion in oligodendroglial tumors. Journal of neuro-oncology 2015 Nov;125(2):249-51.

8. Koschmann C, Calinescu AA, Nunez FJ, et al. ATRX loss promotes tumor growth and impairs nonhomologous end joining DNA repair in glioma. Science translational medicine 2016 Mar 2;8(328):328ra28.

9. Stupp R, Mason WP, van den Bent MJ, et al. Radiotherapy plus concomitant and adjuvant temozolomide for glioblastoma. The New England journal of medicine 2005 Mar 10;352(10):987-96.

10. Lacroix M, Abi-Said D, Fourney DR, et al. A multivariate analysis of 416 patients with glioblastoma multiforme: prognosis, extent of resection, and survival. Journal of neurosurgery 2001 Aug;95(2):190-8.

11. Smith JS, Chang EF, Lamborn KR, et al. Role of extent of resection in the long-term outcome of low-grade hemispheric gliomas. Journal of clinical oncology : official journal of the American Society of Clinical Oncology 2008 Mar 10;26(8):1338-45.

12. Abhinav K, Yeh FC, Mansouri A, et al. High-definition fiber tractography for the evaluation of perilesional white matter tracts in high-grade glioma surgery. Neuro-oncology 2015 Sep;17(9):1199-209.

13. Chan MD. Recent Technical Advances and Indications for Radiation Therapy in Low-Grade Glioma. Seminars in radiation oncology $2015 \mathrm{Jul} ; 25(3): 189-96$.

14. van den Bent MJ, Dubbink HJ, Sanson M, et al. MGMT promoter methylation is prognostic but not predictive for outcome to adjuvant PCV chemotherapy in anaplastic oligodendroglial tumors: a report from EORTC Brain Tumor Group Study 26951. Journal of clinical oncology : official journal of the American Society of Clinical Oncology 2009 Dec 10;27(35):5881-6.

15. Agarwal S, Manchanda P, Vogelbaum MA, et al. Function of the blood-brain barrier and restriction of drug delivery to invasive glioma cells: findings in an orthotopic rat xenograft model of glioma. Drug metabolism and disposition: the biological fate of chemicals 2013 Jan;41(1):33-9.

16. Jackson CM, Lim M, Drake CG. Immunotherapy for brain cancer: recent progress and future promise. Clinical cancer research : an official journal of the American Association for Cancer Research 2014 Jul 15;20(14):3651-9.

17. Calinescu AA, Kamran N, Baker G, et al. Overview of current immunotherapeutic strategies for glioma. Immunotherapy 2015;7(10):1073-104.

18. Reardon DA, Freeman G, Wu C, et al. Immunotherapy advances for glioblastoma. Neurooncology 2014 Nov;16(11):1441-58.

19. Kim ES, Kim JE, Patel MA, et al. Immune Checkpoint Modulators: An Emerging Antiglioma Armamentarium. J Immunol Res 2016;2016:4683607.

20. Galon J, Angell HK, Bedognetti D, et al. The continuum of cancer immunosurveillance: prognostic, predictive, and mechanistic signatures. Immunity 2013 Jul 25;39(1):11-26. 
21. Gajewski TF, Woo SR, Zha $Y$, et al. Cancer immunotherapy strategies based on overcoming barriers within the tumor microenvironment. Current opinion in immunology 2013 Apr;25(2):268-76.

22. Kim JE, Lim M. The role of checkpoints in the treatment of GBM. Journal of neuro-oncology 2015 Jul;123(3):413-23.

23. Goldmann J, Kwidzinski E, Brandt C, et al. T cells traffic from brain to cervical lymph nodes via the cribroid plate and the nasal mucosa. Journal of leukocyte biology 2006 Oct;80(4):797-801.

24. Cserr HF, Harling-Berg CJ, Knopf PM. Drainage of brain extracellular fluid into blood and deep cervical lymph and its immunological significance. Brain pathology 1992 Oct;2(4):269-76.

25. Davies DC. Blood-brain barrier breakdown in septic encephalopathy and brain tumours. Journal of anatomy 2002 Jun;200(6):639-46.

26. 'Liau LM, Prins RM, Kiertscher SM, et al. Dendritic cell vaccination in glioblastoma patients induces systemic and intracranial T-cell responses modulated by the local central nervous system tumor microenvironment. Clinical cancer research : an official journal of the American Association for Cancer Research 2005 Aug 1;11(15):5515-25.

Describes Phase 1 clinical trial results of DC vaccination with autologous tumor peptides; vaccination induced systemic and intracranial $\mathrm{T}$ cell response, but this response was limited by active tumor progression and TGF-B2 expression.

27. Sampson JH, Aldape KD, Archer GE, et al. Greater chemotherapy-induced lymphopenia enhances tumor-specific immune responses that eliminate EGFRvIIt-expressing tumor cells in patients with glioblastoma. Neuro-oncology 2011 Mar;13(3):324-33.

28. Heimberger $A B$, Kong $L Y$, Abou-Ghazal $M$, et al. The role of tregs in human glioma patients and their inhibition with a novel STAT-3 inhibitor. Clin Neurosurg 2009;56:98-106.

29. Zhang JG, Kruse CA, Driggers L, et al. Tumor antigen precursor protein profiles of adult and pediatric brain tumors identify potential targets for immunotherapy. Journal of neuro-oncology 2008 May;88(1):65-76.

30. Grossman SA, Ye X, Lesser $\mathrm{G}$, et al. Immunosuppression in patients with high-grade gliomas treated with radiation and temozolomide. Clinical cancer research : an official journal of the American Association for Cancer Research 2011 Aug 15;17(16):5473-80.

31. Razavi SM, Lee KE, Jin BE, et al. Immune Evasion Strategies of Glioblastoma. Front Surg 2016;3:11.

32. Jordan JT, Sun W, Hussain SF, et al. Preferential migration of regulatory T cells mediated by glioma-secreted chemokines can be blocked with chemotherapy. Cancer Immunol Immunother 2008 Jan;57(1):123-31.

33. Bloch O, Crane CA, Kaur R, et al. Gliomas promote immunosuppression through induction of B7$\mathrm{H} 1$ expression in tumor-associated macrophages. Clinical cancer research : an official journal of the American Association for Cancer Research 2013 Jun 15;19(12):3165-75.

34. Gabrilovich DI, Nagaraj S. Myeloid-derived suppressor cells as regulators of the immune system. Nature reviews Immunology 2009 Mar;9(3):162-74.

35. Facoetti A, Nano R, Zelini P, et al. Human leukocyte antigen and antigen processing machinery component defects in astrocytic tumors. Clinical cancer research : an official journal of the American Association for Cancer Research 2005 Dec 1;11(23):8304-11.

36. Kren L, Slaby O, Muckova K, et al. Expression of immune-modulatory molecules HLA-G and HLAE by tumor cells in glioblastomas: an unexpected prognostic significance? Neuropathology 2011 Apr;31(2):129-34.

37. Wastowski IJ, Simoes RT, Yaghi L, et al. Human leukocyte antigen-G is frequently expressed in glioblastoma and may be induced in vitro by combined 5-aza-2'-deoxycytidine and interferon-gamma treatments: results from a multicentric study. Am J Pathol 2013 Feb;182(2):540-52. 
38. Xu LW, Chow KK, Lim M, et al. Current vaccine trials in glioblastoma: a review. J Immunol Res 2014;2014:796856.

39. Badie B, Schartner J, Prabakaran S, et al. Expression of Fas ligand by microglia: possible role in glioma immune evasion. J Neuroimmunol 2001 Nov 1;120(1-2):19-24.

40. ${ }^{* *}$ Egen JG, Kuhns MS, Allison JP. CTLA-4: new insights into its biological function and use in tumor immunotherapy. Nat Immunol 2002 Jul;3(7):611-8.

This review summarizes the role of CTLA-4 in negatively regulating T cell response and demonstrates the potential of CTLA-4 as an immunotherapeutic target.

41. ${ }^{* *}$ Peggs KS, Quezada SA, Chambers CA, et al. Blockade of CTLA-4 on both effector and regulatory T cell compartments contributes to the antitumor activity of anti-CTLA-4 antibodies. J Exp Med 2009 Aug 3;206(8):1717-25.

Demonstrates the ability of CTLA-4 blockade to produce synergistic antitumor activity through enhancement of effector $T$ cell function and inhibition of regulatory $T$ cell function.

42. Tarhini AA, Kirkwood JM. CTLA-4-blocking immunotherapy with ipilimumab for advanced melanoma. Oncology (Williston Park) 2010 Dec;24(14):1302, 04.

43. Pardoll DM. The blockade of immune checkpoints in cancer immunotherapy. Nat Rev Cancer 2012 Apr;12(4):252-64.

44. Grosso JF, Kelleher CC, Harris TJ, et al. LAG-3 regulates CD8+ T cell accumulation and effector function in murine self- and tumor-tolerance systems. J Clin Invest 2007 Nov;117(11):3383-92.

45. Berghoff AS, Kiesel B, Widhalm G, et al. Programmed death ligand 1 expression and tumorinfiltrating lymphocytes in glioblastoma. Neuro-oncology 2015 Aug;17(8):1064-75.

46. Liu Z, Han H, He X, et al. Expression of the galectin-9-Tim-3 pathway in glioma tissues is associated with the clinical manifestations of glioma. Oncol Lett 2016 Mar;11(3):1829-34.

47. Chen DS, Mellman I. Oncology meets immunology: the cancer-immunity cycle. Immunity 2013 Jul 25;39(1):1-10.

48. Driessens G, Kline J, Gajewski TF. Costimulatory and coinhibitory receptors in anti-tumor immunity. Immunol Rev 2009 May;229(1):126-44.

49. Jackson C, Ruzevick J, Phallen J, et al. Challenges in immunotherapy presented by the glioblastoma multiforme microenvironment. Clin Dev Immunol 2011;2011:732413.

50. Saikali S, Avril T, Collet B, et al. Expression of nine tumour antigens in a series of human glioblastoma multiforme: interest of EGFRvIII, IL-13Ralpha2, gp100 and TRP-2 for immunotherapy. Journal of neuro-oncology 2007 Jan;81(2):139-48.

51. Bakdash G, Sittig SP, van Dijk T, et al. The nature of activatory and tolerogenic dendritic cellderived signal II. Front Immunol 2013;4:53.

52. Joller N, Hafler JP, Brynedal B, et al. Cutting edge: TIGIT has T cell-intrinsic inhibitory functions. J Immunol 2011 Feb 1;186(3):1338-42.

53. Hastings WD, Anderson DE, Kassam N, et al. TIM-3 is expressed on activated human CD4+ T cells and regulates Th1 and Th17 cytokines. Eur J Immunol 2009 Sep;39(9):2492-501.

54. Schwartz RH. Costimulation of T lymphocytes: the role of CD28, CTLA-4, and B7/BB1 in interleukin-2 production and immunotherapy. Cell 1992 Dec 24;71(7):1065-8.

Summarizes the interactions of CD28 and CTLA-4 with B7/BB1 and describes the role of these signaling pathways in IL-2 production and T cell activation.

55. $\quad{ }^{* *}$ Linsley PS, Greene JL, Brady W, et al. Human B7-1 (CD80) and B7-2 (CD86) bind with similar avidities but distinct kinetics to CD28 and CTLA-4 receptors. Immunity 1994 Dec;1(9):793-801. 
Demonstrates that B7-1 (CD80) and B7-2 (CD86) show similar overall receptor binding and $T$ cell costimulatory properties, but B7-1 binds CTLA4 more readily and dissociates from CTLA-4 more slowly than B7-2.

56. Hodi FS, O'Day SJ, McDermott DF, et al. Improved survival with ipilimumab in patients with metastatic melanoma. The New England journal of medicine 2010 Aug 19;363(8):711-23.

57. ${ }^{* *}$ Margolin K, Ernstoff MS, Hamid O, et al. Ipilimumab in patients with melanoma and brain metastases: an open-label, phase 2 trial. Lancet Oncol 2012 May;13(5):459-65.

Demonstrates the activity of ipilimumab in patients with advanced melanoma and brain metastases, and shows that ipilimumab does not produce unexpected adverse effects in this population.

58. Queirolo P, Spagnolo F, Ascierto PA, et al. Efficacy and safety of ipilimumab in patients with advanced melanoma and brain metastases. Journal of neuro-oncology 2014 May;118(1):109-16.

59. Company B-MS. Yervoy (ipilimumab) [prescribing information]. 2013 [cited; Available from: http://www.yervoy.com

60. Fecci PE, Ochiai $H$, Mitchell DA, et al. Systemic CTLA-4 blockade ameliorates glioma-induced changes to the $\mathrm{CD} 4+\mathrm{T}$ cell compartment without affecting regulatory $\mathrm{T}$-cell function. Clinical cancer research : an official journal of the American Association for Cancer Research 2007 Apr 1;13(7):2158-67.

61. Vom Berg J, Vrohlings $M$, Haller S, et al. Intratumoral $1 L-12$ combined with CTLA-4 blockade elicits T cell-mediated glioma rejection. J Exp Med 2013 Dec 16;210(13):2803-11.

62. Agarwalla P, Barnard Z, Fecci P, et al. Sequential immunotherapy by vaccination with GM-CSFexpressing glioma cells and CTLA-4 blockade effectively treats established murine intracranial tumors. Journal of immunotherapy 2012 Jun;35(5):385-9.

63. Topalian SL, Hodi FS, Brahmer JR, et al. Safety, activity, and immune correlates of anti-PD-1 antibody in cancer. The New England journal of medicine 2012 Jun 28;366(26):2443-54.

64. Eppihimer MJ, Gunn J, Freeman GJ, et al. Expression and regulation of the PD-L1 immunoinhibitory molecule on microvascular endothelial cells. Microcirculation 2002 Apr;9(2):133-45.

65. Liu Y, Carlsson R, Ambjorn M, et al. PD-L1 expression by neurons nearby tumors indicates better prognosis in glioblastoma patients. J Neurosci 2013 Aug 28;33(35):14231-45.

66. Wolchok JD, Kluger $\mathrm{H}$, Callahan MK, et al. Nivolumab plus ipilimumab in advanced melanoma. The New England journal of medicine 2013 Jul 11;369(2):122-33.

67. Weber JS, Kudchadkar RR, YU B, et al. Safety, efficacy, and biomarkers of nivolumab with vaccine in ipilimumab-refractory or -naive melanoma. Journal of clinical oncology : official journal of the American Society of Clinical Oncology 2013 Dec 1;31(34):4311-8.

68. Company B-MS. Opdivo (nivolumab) [prescribing information]. 2014 [cited; Available from: http://www.opdivo.bmscustomerconnect.com/gateway

69. Merck \& Co. I. Keytruda (pembrolizumab) [prescribing information]. 2015 [cited; Available from: http://www.merck.com/product/usa/pi circulars/k/keytruda/keytruda pi.pdf

70. Ansell SM, Lesokhin AM, Borrello I, et al. PD-1 blockade with nivolumab in relapsed or refractory Hodgkin's lymphoma. The New England journal of medicine 2015 Jan 22;372(4):311-9.

71. Scott JA. Nivolumab (anti-PD-1; BMS-936558, ONO-4538) and ipilimumab in first-line NSCLC: Interim phase I results. J Clin Oncol 2014;32 (15 Suppl.).

72. "Preusser M, Lim M, Hafler DA, et al. Prospects of immune checkpoint modulators in the treatment of glioblastoma. Nat Rev Neurol 2015 Sep;11(9):504-14.

Summarizes preclinical and clinical studies of immune checkpoint modulators in glioblastoma and outlines specific challenges in clinical development of checkpoint modulators.

73. Hafler DA, Kuchroo V. TIMs: central regulators of immune responses. J Exp Med 2008 Nov 24;205(12):2699-701. 
74. Anderson AC. Tim-3: an emerging target in the cancer immunotherapy landscape. Cancer immunology research 2014 May;2(5):393-8.

75. Han S, Feng S, Xu L, et al. Tim-3 on peripheral CD4(+) and CD8(+) T cells is involved in the development of glioma. DNA Cell Biol 2014 Apr;33(4):245-50.

76. Zeng J, See AP, Phallen J, et al. Anti-PD-1 blockade and stereotactic radiation produce long-term survival in mice with intracranial gliomas. Int J Radiat Oncol Biol Phys 2013 Jun 1;86(2):343-9.

77. Uyttenhove C, Pilotte L, Theate I, et al. Evidence for a tumoral immune resistance mechanism based on tryptophan degradation by indoleamine 2,3-dioxygenase. Nat Med 2003 Oct;9(10):1269-74.

78. Wainwright DA, Balyasnikova IV, Chang AL, et al. IDO expression in brain tumors increases the recruitment of regulatory $T$ cells and negatively impacts survival. Clinical cancer research : an official journal of the American Association for Cancer Research 2012 Nov 15;18(22):6110-21.

79. 'Wainwright DA, Chang AL, Dey $M$, et al. Durable therapeutic efficacy utilizing combinatorial blockade against IDO, CTLA-4, and PD-L1 in mice with brain tumors. Clinical cancer research : an official journal of the American Association for Cancer Research 2014 Oct 15;20(20):5290-301.

Reports preclinical evidence that combinatorial blockade of IDO, CTLA-4, and PDL- 1 in mouse models of GBM decreases tumor-infiltrating regulatory $T$ cells and mediates long term survival.

80. Baixeras E, Huard B, Miossec C, et al. Characterization of the lymphocyte activation gene 3encoded protein. A new ligand for human leukocyte antigen class II antigens. J Exp Med 1992 Aug 1;176(2):327-37.

81. Woo SR, Turnis ME, Goldberg MV, et al. Immune inhibitory molecules LAG-3 and PD-1 synergistically regulate T-cell function to promote tumoral immune escape. Cancer research 2012 Feb 15;72(4):917-27.

82. Grossauer S, Koeck, K., Petritsch, C. Immunecheckpoint blockage - a promising strategy to overcome glioma stem cell therapy-resistance. Insights in Neurosurgery 2016;Vol. 1 No. 1:1.

83. Castro MG, Candolfi M, Wilson TJ, et al. Adenoviral vector-mediated gene therapy for gliomas: coming of age. Expert opinion on biological therapy 2014 Sep;14(9):1241-57.

84. Kane JR, Miska J, Young JS, et al. Sui generis: gene therapy and delivery systems for the treatment of glioblastoma. Neuro-oncology 2015 Mar;17 Suppl 2:ii24-ii36.

85. Workenhe ST, Mossman KL. Oncolytic virotherapy and immunogenic cancer cell death: sharpening the sword for improved cancer treatment strategies. Molecular therapy : the journal of the American Society of Gene Therapy 2014 Feb;22(2):251-6.

86. "Krysko DV, Garg AD, Kaczmarek A, et al. Immunogenic cell death and DAMPs in cancer therapy. Nat Rev Cancer 2012 Dec;12(12):860-75.

Summarizes mechanisms which regulate immunogenicity of dying cancer cells.

87. Curtin JF, Liu N, Candolfi M, et al. HMGB1 mediates endogenous TLR2 activation and brain tumor regression. PLoS medicine 2009 Jan 13;6(1):e10.

Describes a novel mechanism of anti-GBM immune stimulation through TLR2 signaling mediated by release of HMGB1 by dying tumor cells.

88. Duarte $\mathrm{S}$, Carle $\mathrm{G}$, Faneca $\mathrm{H}$, et al. Suicide gene therapy in cancer: where do we stand now? Cancer letters 2012 Nov 28;324(2):160-70.

89. Okura H, Smith C, Rutka J. Gene therapy for malignant glioma. Mol and Cell Ther 2014 2014/07/08;2(1):1-19.

90. Tobias A, Ahmed A, Moon KS, et al. The art of gene therapy for glioma: a review of the challenging road to the bedside. Journal of neurology, neurosurgery, and psychiatry 2013 Feb;84(2):21322. 
91. Prados MD, McDermott M, Chang SM, et al. Treatment of progressive or recurrent glioblastoma multiforme in adults with herpes simplex virus thymidine kinase gene vector-producer cells followed by intravenous ganciclovir administration: a phase I/II multi-institutional trial. Journal of neuro-oncology 2003 Dec;65(3):269-78.

92. Germano IM, Emdad L, Qadeer ZA, et al. Embryonic stem cell (ESC)-mediated transgene delivery induces growth suppression, apoptosis and radiosensitization, and overcomes temozolomide resistance in malignant gliomas. Cancer gene therapy 2010 Sep;17(9):664-74.

93. Rainov NG. A phase III clinical evaluation of herpes simplex virus type 1 thymidine kinase and ganciclovir gene therapy as an adjuvant to surgical resection and radiation in adults with previously untreated glioblastoma multiforme. Hum Gene Ther 2000 Nov 20;11(17):2389-401.

94. Maraskovsky E, Brasel $\mathrm{K}$, Teepe $\mathrm{M}$, et al. Dramatic increase in the numbers of functionally mature dendritic cells in Flt3 ligand-treated mice: multiple dendritic cell subpopulations identified. J Exp Med 1996 Nov 1;184(5):1953-62.

95. Ali S, Curtin JF, Zirger JM, et al. Inflammatory and anti-glioma effects of an adenovirus expressing human soluble Fms-like tyrosine kinase 3 ligand (hsFlt3L): treatment with hsFlt3L inhibits intracranial glioma progression. Molecular therapy : the journal of the American Society of Gene Therapy 2004 Dec;10(6):1071-84.

96. ${ }^{* *}$ Ali S, King GD, Curtin JF, et al. Combined immunostimulation and conditional cytotoxic gene therapy provide long-term survival in a large glioma model. Cancer research 2005 Aug 15;65(16):7194204.

Demonstrates the requirement of tumor cell killing through HSV1-TK therapy combined with immunostimulation through Flt3L to produce an effective anti-glioma response

97. Candolfi M, Curtin JF, Yagiz K, et al. B cells are critical to T-cell-mediated antitumor immunity induced by a combined immune-stimulatory/conditionally cytotoxic therapy for glioblastoma. Neoplasia 2011 Oct;13(10):947-60.

98. King GD, Muhammad AK, Curtin JF, et al. FIt3L and TK gene therapy eradicate multifocal glioma in a syngeneic glioblastoma model. Neuro-oncology 2008 Feb;10(1):19-31.

99. King GD, Muhammad AK, Larocque $D$, et al. Combined Flt3L/TK gene therapy induces immunological surveillance which mediates an immune response against a surrogate brain tumor neoantigen. Molecular therapy : the journal of the American Society of Gene Therapy 2011 Oct;19(10):1793-801.

100. Aghi M, Martuza RL. Oncolytic viral therapies - the clinical experience. Oncogene 2005 Nov 21;24(52):7802-16.

101. Cassady KA, Parker JN. Herpesvirus vectors for therapy of brain tumors. The open virology journal 2010;4:103-8.

102. Myers R, Harvey M, Kaufmann TJ, et al. Toxicology study of repeat intracerebral administration of a measles virus derivative producing carcinoembryonic antigen in rhesus macaques in support of a phase I/II clinical trial for patients with recurrent gliomas. Hum Gene Ther 2008 Jul;19(7):690-8.

103. Forsyth P, Roldan G, George D, et al. A phase I trial of intratumoral administration of reovirus in patients with histologically confirmed recurrent malignant gliomas. Molecular therapy : the journal of the American Society of Gene Therapy 2008 Mar;16(3):627-32.

104. Kim JW, Kane JR, Young JS, et al. A Genetically Modified Adenoviral Vector with a Phage DisplayDerived Peptide Incorporated into Fiber Fibritin Chimera Prolongs Survival in Experimental Glioma. Hum Gene Ther 2015 Sep;26(9):635-46.

105. Nandi S, Ulasov IV, Tyler MA, et al. Low-dose radiation enhances survivin-mediated virotherapy against malignant glioma stem cells. Cancer research $2008 \mathrm{Jul}$ 15;68(14):5778-84. 
106. Kirn D, Hermiston T, McCormick F. ONYX-015: clinical data are encouraging. Nat Med 1998 Dec;4(12):1341-2.

107. Chiocca EA, Abbed KM, Tatter S, et al. A phase I open-label, dose-escalation, multi-institutional trial of injection with an E1B-Attenuated adenovirus, ONYX-015, into the peritumoral region of recurrent malignant gliomas, in the adjuvant setting. Molecular therapy : the journal of the American Society of Gene Therapy 2004 Nov;10(5):958-66.

108. Lang FF, Conrad C, Gomez-Manzano C, et al. FIRST-IN-HUMAN PHASE I CLINICAL TRIAL OF ONCOLYTIC DELTA-24-RGD (DNX-2401) WITH BIOLOGICAL ENDPOINTS: IMPLICATIONS FOR VIROIMMUNOTHERAPY. Neuro-oncology 2014 July 1, 2014;16(suppl 3):iii39.

109. Jacobs SK, Wilson DJ, Kornblith PL, et al. Interleukin-2 or autologous lymphokine-activated killer cell treatment of malignant glioma: phase I trial. Cancer research 1986 Apr;46(4 Pt 2):2101-4.

110. Holladay FP, Heitz-Turner T, Bayer WL, et al. Autologous tumor cell vaccination combined with adoptive cellular immunotherapy in patients with grade III/IV astrocytoma. Journal of neuro-oncology 1996 Feb;27(2):179-89.

111. Colombo F, Barzon L, Franchin E, et al. Combined HSV-TK/IL-2 gene therapy in patients with recurrent glioblastoma multiforme: biological and clinical results. Cancer gene therapy 2005 Oct;12(10):835-48.

112. Okada H, Giezeman-Smits KM, Tahara $\mathrm{H}$, et al. Effective cytokine gene therapy against an intracranial glioma using a retrovirally transduced IL-4 plus HSVtk tumor vaccine. Gene therapy 1999 Feb;6(2):219-26.

113. Okada H, Pollack IF, Lotze MT, et al. Gene therapy of malignant gliomas: a phase I study of IL-4HSV-TK gene-modified autologous tumor to elicit an immune response. Hum Gene Ther 2000 Mar 1;11(4):637-53.

114. Natsume A, Ishii D, Wakabayashi T, et al. IFN-beta down-regulates the expression of DNA repair gene MGMT and sensitizes resistant glioma cells to temozolomide. Cancer research 2005 Sep 1;65(17):7573-9.

115. Natsume A, Wakabayashi T, Ishii D, et al. A combination of IFN-beta and temozolomide in human glioma xenograft models: implication of p53-mediated MGMT downregulation. Cancer chemotherapy and pharmacology 2008 Apr;61(4):653-9.

116. Wakabayashi T, Natsume A, Hashizume Y, et al. A phase I clinical trial of interferon-beta gene therapy for high-grade glioma: novel findings from gene expression profiling and autopsy. The journal of gene medicine 2008 Apr;10(4):329-39.

117. Chiocca EA, Smith KM, McKinney B, et al. A phase I trial of Ad.hIFN-beta gene therapy for glioma. Molecular therapy : the journal of the American Society of Gene Therapy 2008 Mar;16(3):61826.

118. Schumacher TN, Schreiber RD. Neoantigens in cancer immunotherapy. Science 2015 Apr 3;348(6230):69-74.

119. Heemskerk B, Kvistborg P, Schumacher TN. The cancer antigenome. The EMBO journal 2013 Jan 23;32(2):194-203.

120. Heimberger AB, Suki D, Yang D, et al. The natural history of EGFR and EGFRvIll in glioblastoma patients. Journal of translational medicine 2005 Oct 19;3:38.

121. *Schumacher $T$, Bunse $L$, Pusch $S$, et al. A vaccine targeting mutant IDH1 induces antitumour immunity. Nature 2014 Aug 21;512(7514):324-7.

Presents a novel IDH1 peptide vaccine which induces antigen-specific T cell response and tumor control in mouse models. 
122. Hou $\mathrm{Y}$, Kohanbash $\mathrm{G}$, Okada $\mathrm{K}$, et al. Novel and shared neoantigen for glioma $\mathrm{T}$ cell therapy derived from histone 3 variant H3. 3 K27M mutation. Journal for immunotherapy of cancer 2015;3(Suppl 2):P445.

123. Burnet FM. Immunological aspects of malignant disease. Lancet 1967 Jun 3;1(7501):1171-4.

124. Baldwin RW, Robins RA. Factors interfering with immunological rejection of tumours. British medical bulletin 1976 May;32(2):118-23.

125. Doll R, Kinlen L. Immunosurveillance and cancer: epidemiological evidence. British medical journal 1970 Nov 14;4(5732):420-2.

126. Munn DH, Bronte V. Immune suppressive mechanisms in the tumor microenvironment. Current opinion in immunology $2016 \mathrm{Apr} ; 39: 1-6$.

127. Sampson JH, Heimberger AB, Archer GE, et al. Immunologic escape after prolonged progressionfree survival with epidermal growth factor receptor variant III peptide vaccination in patients with newly diagnosed glioblastoma. Journal of clinical oncology : official journal of the American Society of Clinical Oncology 2010 Nov 1;28(31):4722-9.

128. Babu R, Adamson DC. Rindopepimut: an evidence-based review of its therapeutic potential in the treatment of EGFRvIII-positive glioblastoma. Core evidence 2012;7:93-103.

129. Schuster J, Lai RK, Recht LD, et al. A phase II, multicenter trial of rindopepimut (CDX-110) in newly diagnosed glioblastoma: the ACT III study. Neuro-oncology 2015 Jan 13.

130. <CLDX_News_2016_3_7_General_Releases.pdf>.

131. *Pollack IF, Jakacki RI, Butterfield LH, et al. Antigen-specific immune responses and clinical outcome after vaccination with glioma-associated antigen peptides and polyinosinic-polycytidylic acid stabilized by lysine and carboxymethylcellulose in children with newly diagnosed malignant brainstem and nonbrainstem gliomas. Journal of clinical oncology : official journal of the American Society of Clinical Oncology 2014 Jul 1;32(19):2050-8.

Reports antigen-specific immune response and clinical response in children with malignant gliomas vaccinated with the combinatorial peptide vaccine containing EphA2, IL-13R $\alpha 2$, and survivin peptides.

132. Phuphanich S, Wheeler CJ, Rudnick JD, et al. Phase I trial of a multi-epitope-pulsed dendritic cell vaccine for patients with newly diagnosed glioblastoma. Cancer Immunol Immunother 2013 Jan;62(1):125-35.

133. Hadrup SR, Bakker AH, Shu CJ, et al. Parallel detection of antigen-specific T-cell responses by multidimensional encoding of MHC multimers. Nature methods 2009 Jul;6(7):520-6.

134. van Rooij N, van Buuren MM, Philips $D$, et al. Tumor exome analysis reveals neoantigen-specific T-cell reactivity in an ipilimumab-responsive melanoma. Journal of clinical oncology : official journal of the American Society of Clinical Oncology 2013 Nov 10;31(32):e439-42.

135. Carreno BM, Magrini V, Becker-Hapak M, et al. Cancer immunotherapy. A dendritic cell vaccine increases the breadth and diversity of melanoma neoantigen-specific T cells. Science 2015 May 15;348(6236):803-8.

136. Gandhi SJ, Minn AJ, Vonderheide $\mathrm{RH}$, et al. Awakening the immune system with radiation: Optimal dose and fractionation. Cancer letters 2015 Nov 28;368(2):185-90.

137. Corso CD, Ali AN, Diaz R. Radiation-induced tumor neoantigens: imaging and therapeutic implications. American journal of cancer research 2011;1(3):390-412.

138. Golden EB, Frances D, Pellicciotta I, et al. Radiation fosters dose-dependent and chemotherapyinduced immunogenic cell death. Oncoimmunology 2014;3:e28518.

139. Wild-Bode C, Weller M, Rimner A, et al. Sublethal irradiation promotes migration and invasiveness of glioma cells: implications for radiotherapy of human glioblastoma. Cancer research 2001 Mar 15;61(6):2744-50. 
140. Zeng J, See AP, Phallen J, et al. Anti-PD-1 blockade and stereotactic radiation produce long-term survival in mice with intracranial gliomas. International journal of radiation oncology, biology, physics 2013 Jun 1;86(2):343-9.

141. Tinhofer I, Niehr F, Konschak R, et al. Next-generation sequencing: hype and hope for development of personalized radiation therapy? Radiation oncology 2015;10:183.

142. Prins RM, Soto H, Konkankit V, et al. Gene expression profile correlates with T-cell infiltration and relative survival in glioblastoma patients vaccinated with dendritic cell immunotherapy. Clinical cancer research : an official journal of the American Association for Cancer Research 2011 Mar 15;17(6):1603-15.

143. Okada $\mathrm{H}$, Kalinski $\mathrm{P}$, Ueda $\mathrm{R}$, et al. Induction of CD8+ T-cell responses against novel gliomaassociated antigen peptides and clinical activity by vaccinations with \{alpha\}-type 1 polarized dendritic cells and polyinosinic-polycytidylic acid stabilized by lysine and carboxymethylcellulose in patients with recurrent malignant glioma. Journal of clinical oncology : official journal of the American Society of Clinical Oncology 2011 Jan 20;29(3):330-6.

144. ${ }^{* *}$ Mitchell DA, Batich KA, Gunn MD, et al. Tetanus toxoid and CCL3 improve dendritic cell vaccines in mice and glioblastoma patients. Nature 2015 Mar 19;519(7543):366-9.

Demonstrates the ability of vaccine site preconditioning with tetanus toxoid to enhance DC migration and improve survival in GBM patients.

145. Ishikawa E, Muragaki $Y$, Yamamoto $T$, et al. Phase $\mathrm{V} /$ lla trial of fractionated radiotherapy, temozolomide, and autologous formalin-fixed tumor vaccine for newly diagnosed glioblastoma. Journal of neurosurgery 2014 Sep;121(3):543-53.

146. Bloch O, Crane CA, Fuks $Y$, et al. Heat-shock protein peptide complex-96 vaccination for recurrent glioblastoma: a phase II, single-arm trial. Neuro-oncology 2014 Jan;16(2):274-9.

147. Kawai T, Akira S. The role of pattern-recognition receptors in innate immunity: update on Tolllike receptors. Nat Immunol 2010 May;11(5):373-84.

148. Hartman LL, Crawford JR, Makale MT, et al. Pediatric phase II trials of poly-ICLC in the management of newly diagnosed and recurrent brain tumors. Journal of pediatric hematology/oncology 2014 Aug;36(6):451-7.

149. Rosenfeld MR, Chamberlain MC, Grossman SA, et al. A multi-institution phase II study of polyICLC and radiotherapy with concurrent and adjuvant temozolomide in adults with newly diagnosed glioblastoma. Neuro-oncology 2010 oct;12(10):1071-7.

150. Carpentier A, Metellus P, Ursu R, et al. Intracerebral administration of CpG oligonucleotide for patients with recurrent glioblastoma: a phase II study. Neuro-oncology $2010 \mathrm{Apr} ; 12$ (4):401-8.

151. Reardon DA, Wucherpfennig KW, Freeman G, et al. An update on vaccine therapy and other immunotherapeutic approaches for glioblastoma. Expert review of vaccines 2013 Jun;12(6):597-615.

152. Chandramohan V, Mitchell DA, Johnson LA, et al. Antibody, T-cell and dendritic cell immunotherapy for malignant brain tumors. Future oncology $2013 \mathrm{Jul} ; 9(7): 977-90$.

153. Niyazi M, Harter PN, Hattingen E, et al. Bevacizumab and radiotherapy for the treatment of glioblastoma: brothers in arms or unholy alliance? Oncotarget 2016 Jan 19;7(3):2313-28.

154. Hegde M, Bielamowicz KJ, Ahmed N. Novel approaches and mechanisms of immunotherapy for glioblastoma. Discovery medicine 2014 Mar;17(93):145-54.

155. Massimino M, Biassoni V, Miceli R, et al. Results of nimotuzumab and vinorelbine, radiation and re-irradiation for diffuse pontine glioma in childhood. Journal of neuro-oncology 2014 Jun;118(2):30512.

156. Westphal M, Heese O, Steinbach JP, et al. A randomised, open label phase III trial with nimotuzumab, an anti-epidermal growth factor receptor monoclonal antibody in the treatment of newly diagnosed adult glioblastoma. European journal of cancer 2015 Mar;51(4):522-32. 
157. Dudley ME, Wunderlich JR, Robbins PF, et al. Cancer regression and autoimmunity in patients after clonal repopulation with antitumor lymphocytes. Science 2002 Oct 25;298(5594):850-4.

158. Morgan RA, Dudley ME, Wunderlich JR, et al. Cancer regression in patients after transfer of genetically engineered lymphocytes. Science 2006 Oct 6;314(5796):126-9.

159. Schuessler A, Smith C, Beagley L, et al. Autologous T-cell therapy for cytomegalovirus as a consolidative treatment for recurrent glioblastoma. Cancer research 2014 Jul 1;74(13):3466-76.

160. Ikeda H, Shiku H. Antigen-receptor gene-modified T cells for treatment of glioma. Advances in experimental medicine and biology 2012;746:202-15.

161. Kahlon KS, Brown C, Cooper LJ, et al. Specific recognition and killing of glioblastoma multiforme by interleukin 13-zetakine redirected cytolytic T cells. Cancer research 2004 Dec 15;64(24):9160-6.

162. Brown CE, Badie B, Barish ME, et al. Bioactivity and Safety of IL13Ralpha2-Redirected Chimeric Antigen Receptor CD8+ T Cells in Patients with Recurrent Glioblastoma. Clinical cancer research : an official journal of the American Association for Cancer Research 2015 Sep 15;21(18):4062-72.

163. Ahmed N, Salsman VS, Kew Y, et al. HER2-specific T cells target primary glioblastoma stem cells and induce regression of autologous experimental tumors. Clinical cancer research : an official journal of the American Association for Cancer Research 2010 Jan 15;16(2):474-85.

164. Kershaw MH, Westwood JA, Darcy PK. Gene-engineered T cells for cancer therapy. Nat Rev Cancer 2013 08//print;13(8):525-41.

165. Johnson LA, Scholler J, Ohkuri T, et al. Rational development and characterization of humanized anti-EGFR variant III chimeric antigen receptor T cells for glioblastoma. Science translational medicine 2015 2015-02-18 00:00:00;7(275):275ra22-75ra22.

166. Castel D, Philippe C, Calmon R, et al. Histone H3F3A and HIST1H3B K27M mutations define two subgroups of diffuse intrinsic pontine gliomas with different prognosis and phenotypes. Acta neuropathologica 2015;130(6):815-27.

167. Siegal T. Clinical Relevance of Prognostic and Predictive Molecular Markers in Gliomas. In: Schramm J, ed. Advances and Technical Standards in Neurosurgery: Volume 43. Cham: Springer International Publishing 2016:91-108.

168. Verhaak RG, Hoadley KA, Purdom E, et al. Integrated genomic analysis identifies clinically relevant subtypes of glioblastoma characterized by abnormalities in PDGFRA, IDH1, EGFR, and NF1. Cancer cell 2010 Jan 19;17(1):98-110.

169. Hsu M, Sedighim S, Wang T, et al. TCR sequencing can identify and track glioma-infiltrating T cells after DC vaccination. Cancer immunology research 2016 Mar 11.

170. Everson RG, Jin RM, Wang $X$, et al. Cytokine responsiveness of CD8(+) T cells is a reproducible biomarker for the clinical efficacy of dendritic cell vaccination in glioblastoma patients. Journal for immunotherapy of cancer 2014;2:10.

171. Avril T, Saikali S, Vauleon E, et al. Distinct effects of human glioblastoma immunoregulatory molecules programmed cell death ligand-1 (PDL-1) and indoleamine 2,3-dioxygenase (IDO) on tumourspecific T cell functions. Journal of neuroimmunology 2010 Aug 25;225(1-2):22-33.

172. Ramirez YP, Weatherbee JL, Wheelhouse RT, et al. Glioblastoma multiforme therapy and mechanisms of resistance. Pharmaceuticals 2013;6(12):1475-506.

173. Zhang RR, Pointer KB, Kuo JS, et al. Mutational analysis reveals the origin and therapy-driven evolution of recurrent glioma. Neurosurgery 2014 Dec;75(6):N9-10.

174. Castro MG, Baker GJ, Lowenstein PR. Blocking immunosuppressive checkpoints for glioma therapy: the more the Merrier! Clinical cancer research : an official journal of the American Association for Cancer Research 2014 Oct 15;20(20):5147-9.

175. Van Meir EG, Hadjipanayis CG, Norden AD, et al. Exciting new advances in neuro-oncology: the avenue to a cure for malignant glioma. CA: a cancer journal for clinicians 2010 May-Jun;60(3):166-93. 
176. Jha P, Suri V, Singh G, et al. Characterization of molecular genetic alterations in GBMs highlights a distinctive molecular profile in young adults. Diagnostic molecular pathology : the American journal of surgical pathology, part B $2011 \mathrm{Dec} ; 20(4): 225-32$.

177. Ohgaki $\mathrm{H}$, Kleihues $\mathrm{P}$. The definition of primary and secondary glioblastoma. Clinical cancer research : an official journal of the American Association for Cancer Research 2013 Feb 15;19(4):764-72.

178. Fontebasso AM, Liu XY, Sturm D, et al. Chromatin remodeling defects in pediatric and young adult glioblastoma: a tale of a variant histone 3 tail. Brain pathology 2013 Mar;23(2):210-6.

179. ${ }^{* *}$ Sturm D, Witt H, Hovestadt V, et al. Hotspot mutations in H3F3A and IDH1 define distinct epigenetic and biological subgroups of glioblastoma. Cancer cell 2012 Oct 16;22(4):425-37.

Defines three subgroups of GBM based on H3F3A and IDH1 mutation which display distinct epigenetic and anatomic characteristics.

180. Lindroth AM, Plass C. Recurrent H3.3 alterations in childhood tumors. Nature genetics 2013 Dec;45(12):1413-4.

181. Liu G, Yuan X, Zeng Z, et al. Analysis of gene expression and chemoresistance of CD133+ cancer stem cells in glioblastoma. Molecular cancer 2006;5:67.

182. Liu G, Yu JS, Zeng G, et al. AIM-2: a novel tumor antigen is expressed and presented by human glioma cells. Journal of immunotherapy 2004 May-Jun;27(3):220-6.

183. Zhang JG, Eguchi J, Kruse CA, et al. Antigenic profiling of glioma cells to generate allogeneic vaccines or dendritic cell-based therapeutics. Clinical cancer research : an official journal of the American Association for Cancer Research 2007 Jan 15;13(2 Pt 1):566-75.

184. Sareddy GR, Panigrahi M, Challa S, et al. Activation of Wnt/beta-catenin/Tcf signaling pathway in human astrocytomas. Neurochemistry international 2009 Sep;55(5):307-17.

185. Liu C, Tu Y, Sun X, et al. Wnt/beta-Catenin pathway in human glioma: expression pattern and clinical/prognostic correlations. Clinical and experimental medicine 2011 Jun;11(2):105-12.

186. Cenci T, Martini M, Montano N, et al. Prognostic relevance of c-Myc and BMI1 expression in patients with glioblastoma. American journal of clinical pathology 2012 Sep;138(3):390-6.

187. Leung $\mathrm{C}$, Lingbeek $\mathrm{M}$, Shakhova $\mathrm{O}$, et al. Bmi1 is essential for cerebellar development and is overexpressed in human medulloblastomas. Nature 2004 Mar 18;428(6980):337-41.

188. Zakrzewska M, Zakrzewski K, Gresner SM, et al. Polycomb genes expression as a predictor of poor clinical outcome in children with medulloblastoma. Child's nervous system : ChNS : official journal of the International Society for Pediatric Neurosurgery 2011 Jan;27(1):79-86.

189. Allan K, Jordan RC, Ang LC, et al. Overexpression of cyclin A and cyclin B1 proteins in astrocytomas. Archives of pathology \& laboratory medicine 2000 Feb;124(2):216-20.

190. Rempel SA, Rosenblum ML, Mikkelsen T, et al. Cathepsin B expression and localization in glioma progression and invasion. Cancer research 1994 Dec 1;54(23):6027-31.

191. Gopinath S, Malla R, Alapati K, et al. Cathepsin B and UPAR regulate self-renewal of gliomainitiating cells through GLI-regulated Sox2 and Bmi1 expression. Carcinogenesis 2013 Mar;34(3):550-9.

192. Sivaparvathi M, Sawaya R, Wang SW, et al. Overexpression and localization of cathepsin B during the progression of human gliomas. Clinical \& experimental metastasis 1995 Jan;13(1):49-56.

193. Barresi V, Buttarelli FR, Vitarelli EE, et al. Caveolin-1 expression in diffuse gliomas: correlation with the proliferation index, epidermal growth factor receptor, $p 53$, and $1 p / 19 q$ status. Human pathology 2009 Dec;40(12):1738-46.

194. Senetta R, Miracco C, Lanzafame S, et al. Epidermal growth factor receptor and caveolin-1 coexpression identifies adult supratentorial ependymomas with rapid unfavorable outcomes. Neurooncology 2011 Feb;13(2):176-83.

195. Singh SK, Clarke ID, Terasaki M, et al. Identification of a cancer stem cell in human brain tumors. Cancer research 2003 Sep 15;63(18):5821-8. 
196. Emlet DR, Gupta P, Holgado-Madruga M, et al. Targeting a glioblastoma cancer stem-cell population defined by EGF receptor variant III. Cancer research 2014 Feb 15;74(4):1238-49.

197. Dahlrot RH, Hansen S, Jensen SS, et al. Clinical value of CD133 and nestin in patients with glioma: a population-based study. International journal of clinical and experimental pathology 2014;7(7):373951.

198. Zhang M, Song T, Yang L, et al. Nestin and CD133: valuable stem cell-specific markers for determining clinical outcome of glioma patients. Journal of experimental \& clinical cancer research . CR 2008;27:85.

199. Kitange GJ, Carlson BL, Schroeder MA, et al. Expression of CD74 in high grade gliomas: a potential role in temozolomide resistance. Journal of neuro-oncology $2010 \mathrm{Nov} ; 100(2): 177-86$.

200. Baron N, Deuster O, Noelker C, et al. Role of macrophage migration inhibitory factor in primary glioblastoma multiforme cells. Journal of neuroscience research 2011 May;89(5):711-7.

201. Shono T, Tofilon PJ, Bruner JM, et al. Cyclooxygenase-2 expression in human gliomas: prognostic significance and molecular correlations. Cancer research 2001 Jun 1;61(11):4375-81.

202. Penas-Prado M, Hess KR, Fisch MJ, et al. Randomized phase II adjuvant factorial study of dosedense temozolomide alone and in combination with isotretinoin, celecoxib, and/or thalidomide for glioblastoma. Neuro-oncology 2015 Feb;17(2):266-73.

203. Eberstal S, Badn W, Fritzell S, et al. Inhibition of cyclooxygenase-2 enhances immunotherapy against experimental brain tumors. Cancer Immunol Immunother 2012 Aug;61(8):1191-9.

204. Lewis-Tuffin L, Rodriguez F, Giannini C, et al. Misregulated E-cadherin expression associated with an aggressive brain tumor phenotype. PloS one 2010;5(10):e13665.

205. Wu W, Tian $\mathrm{Y}, \mathrm{Wan} \mathrm{H}$, et al. Expression of beta-catenin and $\mathrm{E}$ - and $\mathrm{N}$-cadherin in human brainstem gliomas and clinicopathological correlations. The International journal of neuroscience 2013 May;123(5):318-23.

206. Heimberger AB, Sampson JH. The PEPvIII-KLH (CDX-110) vaccine in glioblastoma multiforme patients. Expert opinion on biological therapy 2009 Aug;9(8):1087-98.

207. Wykosky J, Gibo DM, Stanton C, et al. Interleukin-13 receptor alpha 2, EphA2, and Fos-related antigen 1 as molecular denominators of high-grade astrocytomas and specific targets for combinatorial therapy. Clinical cancer research : an official journal of the American Association for Cancer Research 2008 Jan 1;14(1):199-208.

208. Okada H, Kohanbash G, Zhu X, et al. Immunotherapeutic approaches for glioma. Critical reviews in immunology 2009;29(1):1-42.

209. Driggers L, Zhang JG, Newcomb EW, et al. Immunotherapy of pediatric brain tumor patients should include an immunoprevention strategy: a medical hypothesis paper. Journal of neuro-oncology 2010 Apr;97(2):159-69.

210. Ueda R, Low KL, Zhu X, et al. Spontaneous immune responses against glioma-associated antigens in a long term survivor with malignant glioma. Journal of translational medicine 2007;5:68.

211. Orzan F, Pellegatta S, Poliani PL, et al. Enhancer of Zeste 2 (EZH2) is up-regulated in malignant gliomas and in glioma stem-like cells. Neuropathology and applied neurobiology 2011 Jun;37(4):381-94.

212. Scarcella DL, Chow CW, Gonzales MF, et al. Expression of MAGE and GAGE in high-grade brain tumors: a potential target for specific immunotherapy and diagnostic markers. Clinical cancer research : an official journal of the American Association for Cancer Research 1999 Feb;5(2):335-41.

213. Mennel HD, Lell B. Ganglioside (GD2) expression and intermediary filaments in astrocytic tumors. Clinical neuropathology 2005 Jan-Feb;24(1):13-8.

214. Schulz G, Cheresh DA, Varki NM, et al. Detection of ganglioside GD2 in tumor tissues and sera of neuroblastoma patients. Cancer research 1984 Dec;44(12 Pt 1):5914-20.

215. Finocchiaro G, Pellegatta S. Immunotherapy with dendritic cells loaded with glioblastoma stem cells: from preclinical to clinical studies. Cancer Immunol Immunother 2016 Jan;65(1):101-9. 
216. Cantini G, Pisati F, Pessina S, et al. Immunotherapy against the radial glia marker GLAST effectively triggers specific antitumor effectors without autoimmunity. Oncoimmunology 2012 Sep 1;1(6):884-93.

217. Jimeno A, Weiss GJ, Miller WH, Jr., et al. Phase I study of the Hedgehog pathway inhibitor IPI926 in adult patients with solid tumors. Clinical cancer research : an official journal of the American Association for Cancer Research 2013 May 15;19(10):2766-74.

218. Cui $\mathrm{D}, \mathrm{Xu} \mathrm{Q}$, Wang $\mathrm{K}$, et al. Gli1 is a potential target for alleviating multidrug resistance of gliomas. Journal of the neurological sciences 2010 Jan 15;288(1-2):156-66.

219. Rossi M, Magnoni L, Miracco C, et al. beta-catenin and Gli1 are prognostic markers in glioblastoma. Cancer biology \& therapy 2011 Apr 15;11(8):753-61.

220. Yamamoto H, Swoger J, Greene S, et al. Beta1,6-N-acetylglucosamine-bearing N-glycans in human gliomas: implications for a role in regulating invasivity. Cancer research 2000 Jan 1;60(1):134-42.

221. Akiyama Y, Oshita C, Kume A, et al. alpha-type-1 polarized dendritic cell-based vaccination in recurrent high-grade glioma: a phase I clinical trial. BMC cancer 2012;12:623.

222. Liu G, Ying H, Zeng G, et al. HER-2, gp100, and MAGE-1 are expressed in human glioblastoma and recognized by cytotoxic T cells. Cancer research 2004 Jul 15;64(14):4980-6.

223. Xu Q, Liu G, Yuan X, et al. Antigen-specific T-cell response from dendritic cell vaccination using cancer stem-like cell-associated antigens. Stem cells 2009 Aug;27(8):1734-40.

224. Waitkus MS, Diplas BH, Yan H. Isocitrate dehydrogenase mutations in gliomas. Neuro-oncology 2016 Jan;18(1):16-26.

225. Mitchell DA, Cui X, Schmittling RJ, et al. Monoclonal antibody blockade of IL-2 receptor alpha during lymphopenia selectively depletes regulatory T cells in mice and humans. Blood 2011 Sep 15;118(11):3003-12.

226. Mintz A, Gibo DM, Slagle-Webb B, et al. IL-13Ralpha2 is a glioma-restricted receptor for interleukin-13. Neoplasia 2002 Sep-Oct;4(5):388-99.

227. Kogiku M, Ohsawa I, Matsumoto K, et al. Prognosis of glioma patients by combined immunostaining for survivin, Ki-67 and epidermal growth factor receptor. Journal of clinical neuroscience : official journal of the Neurosurgical Society of Australasia 2008 Nov;15(11):1198-203.

228. Persson O, Salford LG, Fransson J, et al. Distribution, cellular localization, and therapeutic potential of the tumor-associated antigen Ku70/80 in glioblastoma multiforme. Journal of neurooncology $2010 \mathrm{Apr} ; 97(2): 207-15$.

229. Bao $S, W u Q, ~ L i ~ Z$, et al. Targeting cancer stem cells through L1CAM suppresses glioma growth. Cancer research 2008 Aug 1;68(15):6043-8.

230. "Cheng L, Wu Q, Huang Z, et al. LICAM regulates DNA damage checkpoint response of glioblastoma stem cells through NBS1. The EMBO journal 2011 Mar 2;30(5):800-13.

Describes a mechanism of glioma stem cell radioresistance through increased DNA damage checkpoint activation by L1CAM signalling and NBS1 upregulation.

231. Bao L, Dunham K, Lucas K. MAGE-A1, MAGE-A3, and NY-ESO-1 can be upregulated on neuroblastoma cells to facilitate cytotoxic $\mathrm{T}$ lymphocyte-mediated tumor cell killing. Cancer Immunol Immunother 2011 Sep;60(9):1299-307.

232. Kuan CT, Srivastava N, McLendon RE, et al. Recombinant single-chain variable fragment antibodies against extracellular epitopes of human multidrug resistance protein MRP3 for targeting malignant gliomas. International journal of cancer 2010 Aug 1;127(3):598-611.

233. Terasaki M, Shibui S, Narita Y, et al. Phase I Trial of a Personalized Peptide Vaccine for Patients Positive for Human Leukocyte Antigen-A24 With Recurrent or Progressive Glioblastoma Multiforme. Journal of Clinical Oncology 2011 January 20, 2011;29(3):337-44. 
234. Ishiwata T, Teduka K, Yamamoto T, et al. Neuroepithelial stem cell marker nestin regulates the migration, invasion and growth of human gliomas. Oncology reports 2011 Jul;26(1):91-9.

235. Dhodapkar MV, Sznol M, Zhao B, et al. Induction of antigen-specific immunity with a vaccine targeting NY-ESO-1 to the dendritic cell receptor DEC-205. Science translational medicine $2014 \mathrm{Apr}$ 16;6(232):232ra51.

236. Rousseau A, Nutt CL, Betensky RA, et al. Expression of oligodendroglial and astrocytic lineage markers in diffuse gliomas: use of YKL-40, ApoE, ASCL1, and NKX2-2. Journal of neuropathology and experimental neurology 2006 Dec;65(12):1149-56.

237. Ligon KL, Huillard E, Mehta $S$, et al. Olig2-regulated lineage-restricted pathway controls replication competence in neural stem cells and malignant glioma. Neuron 2007 Feb 15;53(4):503-17.

238. Ligon KL, Alberta JA, Kho AT, et al. The oligodendroglial lineage marker OLIG2 is universally expressed in diffuse gliomas. Journal of neuropathology and experimental neurology 2004 May;63(5):499-509.

239. Elsir T, Eriksson A, Orrego A, et al. Expression of PROX1 Is a common feature of high-grade malignant astrocytic gliomas. Journal of neuropathology and experimental neurology 2010 Feb;69(2):129-38.

240. Geiger KD, Hendruschk S, Rieber EP, et al. The prostate stem cell antigen represents a novel glioma-associated antigen. Oncology reports 2011 Jul;26(1):13-21.

241. Schmitz M, Temme A, Senner V, et al. Identification of SOX2 as a novel glioma-associated antigen and potential target for T cell-based immunotherapy. British journal of cancer $2007 \mathrm{Apr}$ 23;96(8):1293-301.

242. Favaro R, Appolloni I, Pellegatta S, et al. Sox2 is required to maintain cancer stem cells in a mouse model of high-grade oligodendroglioma. Cancer research 2014 Mar 15;74(6):1833-44.

243. Ueda R, Ohkusu-Tsukada K, Fusaki N, et al. Identification of HLA-A2- and A24-restricted T-cell epitopes derived from SOX6 expressed in glioma stem cells for immunotherapy. International journal of cancer 2010 Feb 15;126(4):919-29.

244. Schmitz M, Wehner R, Stevanovic S, et al. Identification of a naturally processed T cell epitope derived from the glioma-associated protein SOX11. Cancer letters 2007 Jan 8;245(1-2):331-6.

245. Son MJ, Woolard K, Nam DH, et al. SSEA-1 is an enrichment marker for tumor-initiating cells in human glioblastoma. Cell stem cell 2009 May 8;4(5):440-52.

246. Tchirkov A, Rolhion C, Kemeny JL, et al. Clinical implications of quantitative real-time RT-PCR analysis of hTERT gene expression in human gliomas. British journal of cancer $2003 \mathrm{Feb} 24 ; 88(4): 516-20$.

247. Yamamoto M, Sawaya R, Mohanam S, et al. Expression and localization of urokinase-type plasminogen activator receptor in human gliomas. Cancer research 1994 Sep 15;54(18):5016-20.

248. Gondi CS, Lakka SS, Dinh DH, et al. RNAi-mediated inhibition of cathepsin B and uPAR leads to decreased cell invasion, angiogenesis and tumor growth in gliomas. Oncogene 2004 Nov 4;23(52):848696.

249. Izumoto S, Tsuboi A, Oka Y, et al. Phase II clinical trial of Wilms tumor 1 peptide vaccination for patients with recurrent glioblastoma multiforme. Journal of neurosurgery 2008 May;108(5):963-71.

250. Morita S, Oka Y, Tsuboi A, et al. A phase I/II trial of a WT1 (Wilms' tumor gene) peptide vaccine in patients with solid malignancy: safety assessment based on the phase I data. Japanese journal of clinical oncology $2006 \mathrm{Apr} ; 36(4): 231-6$.

251. Nakahara $\mathrm{Y}$, Okamoto $\mathrm{H}$, Mineta $\mathrm{T}$, et al. Expression of the Wilms' tumor gene product WT1 in glioblastomas and medulloblastomas. Brain tumor pathology 2004;21(3):113-6.

252. Shao R, Francescone R, Ngernyuang N, et al. Anti-YKL-40 antibody and ionizing irradiation synergistically inhibit tumor vascularization and malignancy in glioblastoma. Carcinogenesis 2014 Feb;35(2):373-82. 
253. Cobbs CS, Harkins L, Samanta M, et al. Human cytomegalovirus infection and expression in human malignant glioma. Cancer research 2002 Jun 15;62(12):3347-50.

254. dos Santos CJ, Stangherlin LM, Figueiredo EG, et al. High prevalence of HCMV and viral load in tumor tissues and peripheral blood of glioblastoma multiforme patients. Journal of medical virology 2014 Nov;86(11):1953-61.

255. Libard S, Popova SN, Amini RM, et al. Human cytomegalovirus tegument protein pp65 is detected in all intra- and extra-axial brain tumours independent of the tumour type or grade. PloS one 2014;9(9):e108861.

256. Lucas KG, Bao L, Bruggeman R, et al. The detection of CMV pp65 and IE1 in glioblastoma multiforme. Journal of neuro-oncology 2011 Jun;103(2):231-8.

257. Mitchell DA, Xie W, Schmittling R, et al. Sensitive detection of human cytomegalovirus in tumors and peripheral blood of patients diagnosed with glioblastoma. Neuro-oncology 2008 Feb;10(1):10-8.

258. Shamran HA, Kadhim HS, Hussain AR, et al. Detection of human cytomegalovirus in different histopathological types of glioma in Iraqi patients. BioMed research international 2015;2015:642652.

259. Hdeib A, Sloan AE. Dendritic cell immunotherapy for solid tumors: evaluation of the DCVax(R) platform in the treatment of glioblastoma multiforme. CNS oncology 2015;4(2):63-9.

260. Choi Y, Chang J. Viral vectors for vaccine applications. Clinical and experimental vaccine research 2013 Jul;2(2):97-105.

261. Fan Y, Moon JJ. Nanoparticle Drug Delivery Systems Designed to Improve Cancer Vaccines and Immunotherapy. Vaccines 2015;3(3):662-85.

262. Boudreau JE, Bonehill A, Thielemans K, et al Engineering dendritic cells to enhance cancer immunotherapy. Molecular therapy : the journal of the American Society of Gene Therapy 2011 May;19(5):841-53.

263. Caruso DA, Orme LM, Neale AM, et al. Results of a phase 1 study utilizing monocyte-derived dendritic cells pulsed with tumor RNA in children and young adults with brain cancer. Neuro-oncology 2004 Jul;6(3):236-46.

264. Hunn MK, Bauer E, Wood CE, et al. Dendritic cell vaccination combined with temozolomide retreatment: results of a phase I trial in patients with recurrent glioblastoma multiforme. Journal of neuro-oncology 2015 Jan;121(2):319-29.

265. Zussman BM, Engh JA. Outcomes of the ACT III Study: Rindopepimut (CDX-110) Therapy for Glioblastoma. Neurosurgery 2015 Jun;76(6):N17. 
Figure 1: Role of GBM cells in the generation and maintainance of the immunosuppressive tumor microenvironment. GBM cells have a central role in the immunosuppressive nature of tumor microenvironment. GBM cells express membrane-bound and soluble immunosuppressive proteins. FasL induces apoptosis of tumor infiltrating limphocytes. B7 molecules activate CTLA4 and PD-L1 are ligands of immunosuppressive recetors CTLA-4 and PD-1, which inhibit effector $\mathrm{T}$ cells that infiltrate the tumor microenvironment. Downregulation of HLA-I reduces the immunogenicity of GBM cells, which in turn could activate NK cell response against the tumor. However, GBM cells overexpress an alternative MHCI molecule, HLA-G, which inhibits NK and CTL response. The synthesis of antiinflammatory cytokines and chemokines also contribute to the immunosuppressive microenyironment. GBM cells produce CCL2 and TGFbeta and IL-10 which recruit Tregs, myeloid derived suppressor cells (MDSCs) and tumor associated macrophages (TAMs) that in turn inhibit the T cell response. IL-10 also inhibits the function of antigen presenting cells (APCs) within the tumor. 


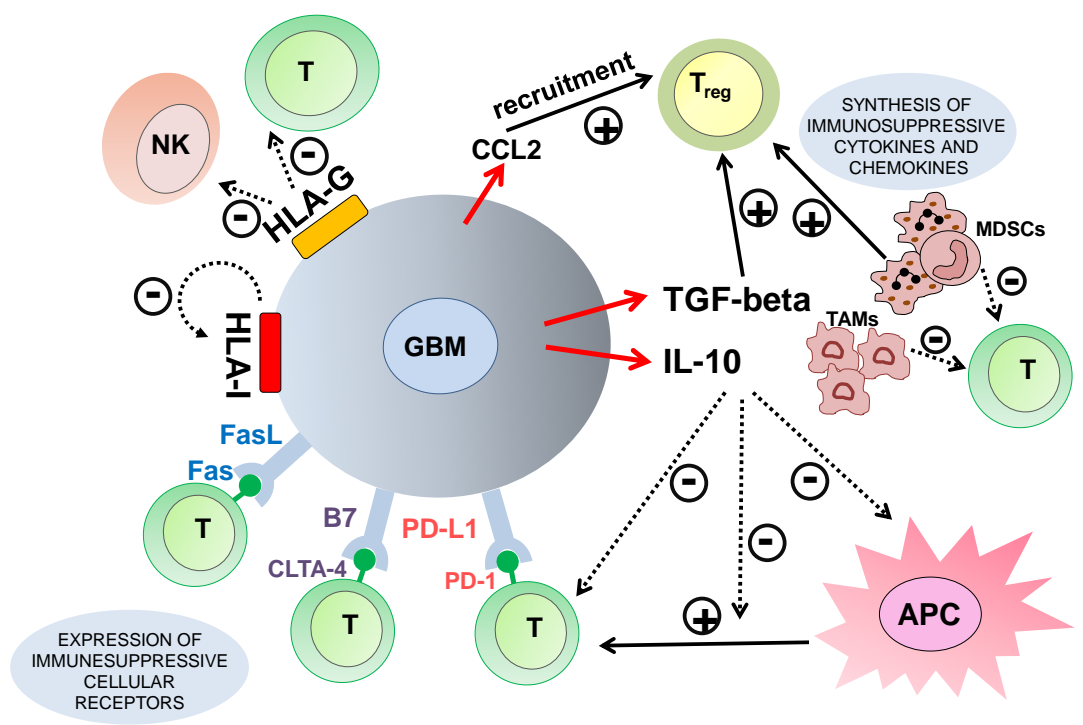

Figure 2: Schematic showing factors that impact vaccination strategy for glioblastoma: (1) preparation and (2) delivery of tumor associated antigens, (3) immune adjuvant to boost immune reactions against tumor antigens and (4) biomarkers to precisely estimate the efficacy of vaccination and to select proper patient populations. Immune adjuvants are divided in two groups: (1) agonists for pro-inflammatory molecules such as TLR agonists or ligation of B7 and CD28 receptors, and (2) antagonists for anti-inflammatory molecules such as anti-PD-1 blocking antibodies or IDO inhibitors. DC represents dendritic cell; CMV, cytomegalovirus; APC, antigen presenting cell, TLR, toll like receptor. 


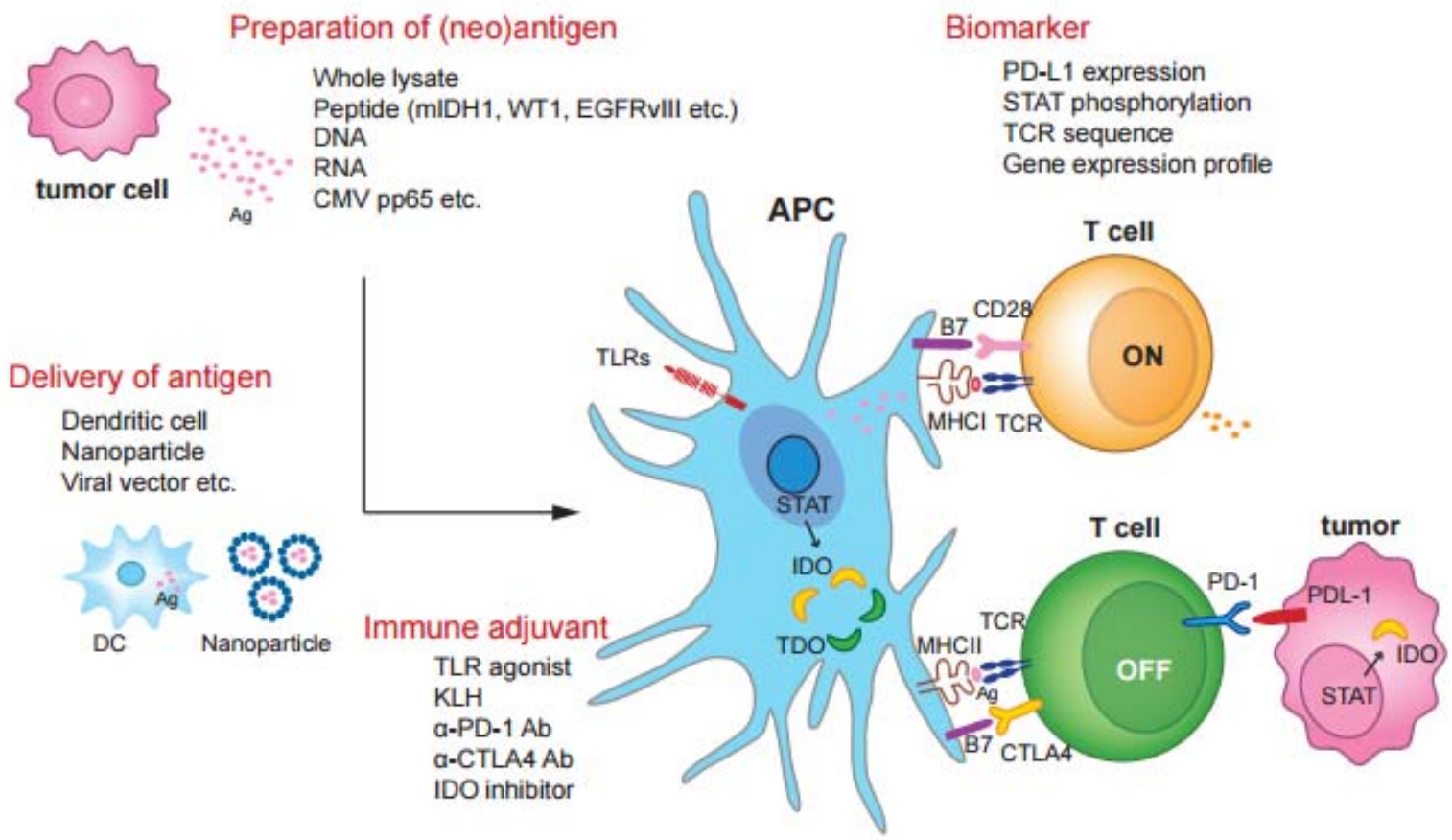


Table 1: Overview of molecular and genetic alterations in glioma

\begin{tabular}{|c|c|c|c|c|}
\hline \multicolumn{5}{|l|}{ Adult Primary } \\
\hline Tumor Subtype & Classical & Mesenchymal & Neural & Proneural \\
\hline overexpression & ${ }_{175} G F R, N E S^{168}$ & $\begin{array}{l}\text { MET, CHI3L1, } \\
\text { CD44, MERTK }^{175}\end{array}$ & $\operatorname{EGFR}(1,2)$ & $P D G F R A^{1}$ \\
\hline $\begin{array}{l}\text { low } \\
\text { expression/ablation }\end{array}$ & $\begin{array}{l}\text { PTEN, } \\
\text { CDKN2A } 168,175\end{array}$ & NF1, PTEN ${ }^{168,175}$ & & $P T$ \\
\hline mutation & $E G F R^{168,175}$ & $\begin{array}{l}\text { NF1 }^{168,175} \\
\text { PTEN }^{168}\end{array}$ & & $\begin{array}{l}I D H 1,2 \\
P I K 3 A / R 1^{168,175}\end{array}$ \\
\hline pathway activity & $\begin{array}{l}\text { Notch }^{168,175} \text {, } \\
\text { Sonic } \\
\text { hedgehog }\end{array}$ & TNF, NFkB $^{168,175}$ & & $\begin{array}{l}\text { HIF, PI3K, } \\
\text { PDGF })^{175}\end{array}$ \\
\hline marker expression & & CHI3L1, MET ${ }^{168}$ & $\begin{array}{l}\text { NEFL, GABRA1, } \\
\text { SYT, SLC1A5 }\end{array}$ & $\begin{array}{l}\text { SOX, DCX, DLL3, } \\
\text { ASCL1, TCF4 }{ }^{168,} \\
175\end{array}$ \\
\hline
\end{tabular}

\begin{tabular}{|l|l|l|}
\hline Tumor Type & Adult Secondary & Young Adult \\
\hline overexpression & $P D G F R A^{175}$ & \\
\hline low expression/ablation & $P T E N^{175,176}$ & $P T E N^{176}$ \\
\hline mutation & $T P 53$, IDH1 $1^{175,176}$, ATR $^{6,177}$ & TP53, IDH $^{176,178}$, H3.G34 $^{178,179}$, \\
\hline pathway activity & HIF, PI3K, PDGFRA & \\
\hline marker expression & PDGFRA, OLIG2, TCF3, NKX2 & \\
\hline
\end{tabular}


Table 2: Glioma associated antigens as therapeutic targets

\begin{tabular}{|c|c|c|c|}
\hline Antigen & Description & Expression & Tested in clinical trials? \\
\hline $\mathrm{ABCG}^{181}$ & $\begin{array}{c}\text { ATP - Binding Cassette } \\
\text { Group }\end{array}$ & Glioma stem cells & \\
\hline Aim-2 29,132, 182, 183 & $\begin{array}{c}\text { Antigen Isolated Melanoma- } \\
2\end{array}$ & High grade astrocytoma & $\begin{array}{l}\text { DC vaccine pulsed with } \\
\text { HER2, TRP-2, gp100, } \\
\text { MAGE-1, IL13R } \alpha 2 \text {, and } \\
\text { AIM-2 peptides } \\
\text { 33\% immune response }\end{array}$ \\
\hline Art1 ${ }^{29}$ & $\begin{array}{l}\text { Antigen Recognized by } \mathrm{T} \\
\text { cells-1 }\end{array}$ & $\begin{array}{c}\text { Adult and pediatric brain } \\
\text { tumors }\end{array}$ & N/A \\
\hline Art4 ${ }^{29}$ & $\begin{array}{c}\text { Antigen Recognized by } \mathrm{T} \\
\text { cells- } 4\end{array}$ & Adult GBM & N/A \\
\hline B-catenin ${ }^{184,185}$ & Beta-catenin & Astrocytomas & N/A \\
\hline BMI1 ${ }^{186-188}$ & polycomb-group (1) & $\begin{array}{l}\text { Medulloblastoma, } \\
\text { Glioblastoma, Glioma stem }\end{array}$ & N/A \\
\hline B-cyclin $29,183,18$ & & Adult GBM & N/A \\
\hline Cathepsin B ${ }^{190-192}$ & & $\begin{array}{l}\text { Glioma stem cells, } \\
\text { glioblastoma }\end{array}$ & N/A \\
\hline & Caveolin -1 & $\begin{array}{l}\text { Anaplastic astrocytoma, } \\
\text { Glioblastoma, } \\
\text { Oligodendroglioma, } \\
\text { Ependymoma }\end{array}$ & N/A \\
\hline CD133 & $\begin{array}{c}\text { Cluster of differentiation 133, } \\
\text { Prominin }\end{array}$ & Glioma stem cells & $\begin{array}{c}\text { ICT-121 DC vaccine pulsed } \\
\text { with CD133 } \\
\text { (NCT02049489) ongoing }\end{array}$ \\
\hline $\mathrm{CD} 74^{199,200}$ & $\begin{array}{c}\text { Cluster of Differentiation } 74, \\
\text { HLA class II } \\
\text { histocompatibility antigen }\end{array}$ & Glioblastoma & N/A \\
\hline
\end{tabular}




\begin{tabular}{|c|c|c|c|}
\hline & $\begin{array}{l}\text { gamma chain } \\
\text { Binds Macrophage Migration } \\
\text { Inhibitory Factor }\end{array}$ & & \\
\hline COX-2 ${ }^{201-203}$ & Cyclo-oxygenase 2 & $\begin{array}{c}\text { Glioblastoma, CD133+ } \\
\text { GSC cells }\end{array}$ & $\begin{array}{c}\text { COX-2 inhibitor celecoxib } \\
\text { and TMZ with thalidomide } \\
\text { or isoretinoin } \\
\text { (NCT00112502) } \\
\text { No difference in PFS or } \\
\text { OS }^{202}\end{array}$ \\
\hline E-Cadherin 204, 205 & $\begin{array}{c}\text { Epithelial-calcium-dependent } \\
\text { adhesion }\end{array}$ & $\begin{array}{l}\text { Glioblastoma, Pontine } \\
\text { glioma, Medulloblastom }\end{array}$ & N/A \\
\hline $\begin{array}{c}\text { EGFRvIII }{ }^{50,127-129}, \\
196,206\end{array}$ & $\begin{array}{l}\text { Epidermal growth factor } \\
\text { receptor variant III } \\
\text { (truncated, constitutively } \\
\text { active form of the receptors) }\end{array}$ & Glioblastoma & $\begin{array}{l}\text { EGFRIII peptide vaccine } \\
\text { ACTIVATE, ACTII } \\
\text { (NCT00643097) } \\
\text { 43\% EGFRvIII-specific } \\
\text { antibody response }{ }^{127} \\
\text { ACTIII (NCT00458601) } \\
\text { 85\% EGFRvIII-specific } \\
\text { antibody response }{ }^{129} \\
\text { ACTIV (NCT01480479) } \\
\text { ongoing } \\
\text { ReACT (NCT01498328) } \\
\text { ongoing } \\
\text { EGFRvIII CARs } \\
\text { NCT02209376 ongoing } \\
\text { NCT01454596 ongoing }\end{array}$ \\
\hline Ephrin A2/Eck ${ }^{29}$ & $\begin{array}{l}\text { Ephrin Receptor A2 } \\
\text { /epithelial cell kinase }\end{array}$ & $\begin{array}{l}\text { Glioma Stem Cells, } \\
\text { Glioblastoma, Adult and } \\
\text { pediatric brain tumors }\end{array}$ & $\begin{array}{c}\text { DC vaccine pulsed with } \\
\text { EphA2, IL-13R } \alpha 2, \text { YKL-40, } \\
\text { and gp100 (NCT00766753) } \\
\text { 58\% immune response }{ }^{143} \\
\text { EphA2, IL-13R } \alpha 2 \text {, and } \\
\text { survivin peptide vaccine } \\
\text { (NCT01130077) } \\
62 \% \text { peptide specific }\end{array}$ \\
\hline
\end{tabular}




\begin{tabular}{|c|c|c|c|}
\hline & & & $\begin{array}{l}\text { immune response }^{131} \\
\text { SL-701 peptide vaccine } \\
\text { (NCT02078648) ongoing }\end{array}$ \\
\hline EZH2 ${ }^{29,209,211}$ & Enhancer of zeste homolog 2 & $\begin{array}{l}\text { Adult GBM, Glioma stem } \\
\text { cells }\end{array}$ & \\
\hline Fra-1/Fosl 1 $19,207,209$ & Fos related antigen 1 & $\begin{array}{l}\text { Adult GBM, highly } \\
\text { expressed in pediatric brain } \\
\text { tumors }\end{array}$ & \\
\hline GAGE-1 ${ }^{29,212}$ & G antigen 1 & $\begin{array}{l}\text { Low expression in adult high } \\
\text { grade and pediatric brain } \\
\text { tumors }\end{array}$ & N/A \\
\hline$\underset{213,214}{\text { Ganglioside/ GD2 }}$ & Gangliosinde GD2 & Astrocyt & N/A \\
\hline GLAST 215,216 & $\begin{array}{c}\text { GLutamate ASpartate } \\
\text { Transporter, Solute carrier } \\
\text { family } 1 \text { (glial high-affinity } \\
\text { glutamate transporter), } \\
\text { member 3, SLC1A3, } \\
\text { Excitatory Amino Acid } \\
\text { Transporter 1 (EAAT1). }\end{array}$ & cells & N/A \\
\hline Gli-1 ${ }^{217-219}$ & $\begin{array}{c}\text { Glioma-associated oncogene } \\
\text { homolog } 1\end{array}$ & $\begin{array}{c}\text { Glioblastoma, recurrent } \\
\text { Glioblastoma after } \\
\text { chemotherapy }\end{array}$ & $\begin{array}{c}\text { IPI-926: Hedgehog pathway } \\
\text { inhibitor } \\
\text { 28\% response } \\
217\end{array}$ \\
\hline $\begin{array}{c}\text { GnT-V, } \beta 1,6-\mathrm{N}^{29,} \\
183,209,220\end{array}$ & b $1.6 \mathrm{~N}$-acetyl & Astrocytoma, Adult GBM & N/A \\
\hline $\begin{array}{c}\mathrm{GP}-100^{29,50,132,143,} \\
183,221,222\end{array}$ & Melanoma Glycoprotein-100 & $\begin{array}{l}\text { Low expression in adult and } \\
\text { pediatric brain tumors }\end{array}$ & $\begin{array}{l}\text { DC vaccine pulsed with } \\
\text { HER2, TRP-2, gp100, } \\
\text { MAGE-1, IL13R } \alpha 2 \text {, and } \\
\text { AIM-2 peptides } \\
\text { 33\% immune response }{ }^{132} \\
\text { DC vaccine pulsed with } \\
\text { EphA2, IL-13R } \alpha 2, \text { YKL-40, } \\
\text { and gp100 (NCT00766753) } \\
\text { 58\% immune response }{ }^{143} \\
\text { DC vaccine pulsed with } \\
\text { WT-1, HER2, MAGE-A3, }\end{array}$ \\
\hline
\end{tabular}




\begin{tabular}{|c|c|c|c|}
\hline & & & $\begin{array}{c}\text { and MAGE-A1 or gp100 } \\
\text { 66\% cellular immune } \\
\text { response }^{221}\end{array}$ \\
\hline $\begin{array}{l}\text { Her-2/Neu }{ }^{29,132,183}, \\
209,221-223\end{array}$ & $\begin{array}{l}\text { HumanEpidermal Growth } \\
\text { Factor Receptor 2, proto- } \\
\text { oncogene Neu, receptor } \\
\text { tyrosine-protein kinase erbB- } \\
\text { 2, CD340 }\end{array}$ & Adult GBM & $\begin{array}{l}\text { DC vaccine pulsed with } \\
\text { HER2, TRP-2, gp100, } \\
\text { MAGE-1, IL13Ra2, and } \\
\text { AIM-2 peptides } \\
\text { 33\% immune response }{ }^{132} \\
\text { DC vaccine pulsed with } \\
\text { WT-1, HER2, MAGE-A3, } \\
\text { and MAGE-A1 or gp100 } \\
\text { 66\% cellular immune } \\
\text { response }{ }^{221} \\
\text { HER-2 CAR } \\
\text { (NCT02442297) ongoing }\end{array}$ \\
\hline IDH1R132H ${ }^{224}$ & $\begin{array}{l}\text { Isocitrate Dehydrogenase } \\
\qquad 1 \text { gene }\end{array}$ & $\begin{array}{l}\text { Mutations present in } \\
\text { majority of several types of } \\
\text { malignant glioma, most } \\
\text { prevalent in secondary GBM }\end{array}$ & $\begin{array}{c}\text { PEPIDH1M: IDH1 peptide } \\
\text { vaccine (NCT02193347) } \\
\text { ongoing } \\
\text { IDH1 peptide vaccine } \\
\text { (NOA-16, NCT02454634) } \\
\text { ongoing }\end{array}$ \\
\hline & $\begin{array}{l}\text { nterleukin } 13 \text { receptor } \\
\text { alpha } 2 \text { protein chain }\end{array}$ & High grade astrocytoma & $\begin{array}{l}\text { DC vaccine pulsed with } \\
\text { HER2, TRP-2, gp100, } \\
\text { MAGE-1, IL13R } \alpha 2 \text {, and } \\
\text { AIM-2 peptides } \\
\text { 33\% immune response }{ }^{132} \\
\text { DC vaccine pulsed with } \\
\text { EphA2, IL-13R } \alpha 2 \text {, YKL-40, } \\
\text { and gp100 (NCT00766753) } \\
\text { 58\% immune response }{ }^{143} \\
\text { EphA2, IL-13R } \alpha 2 \text {, and } \\
\text { survivin peptide vaccine } \\
\text { (NCT01130077) } \\
\text { 62\% peptide specific } \\
\text { immune response }{ }^{131} \\
\text { SL-701 peptide vaccine } \\
\text { (NCT02078648) ongoing }\end{array}$ \\
\hline
\end{tabular}




\begin{tabular}{|c|c|c|c|}
\hline & & & $\begin{array}{c}\text { IL13R } \alpha 2 \text { CAR } \\
\text { (NCT02208362) ongoing }\end{array}$ \\
\hline $\mathrm{Ki}-67^{189,227}$ & $\begin{array}{c}\text { The nuclear cell } \\
\text { proliferation-associated } \\
\text { antigen of antibody Ki-67 }\end{array}$ & $\begin{array}{l}\text { Prognostic marker for low } \\
\text { grade glioma }\end{array}$ & N/A \\
\hline $\mathrm{Ku} 70 / \mathrm{Ku} 80^{228}$ & $\begin{array}{l}\text { Human } \mathrm{Ku} \text { heterodimer } \\
\text { proteins subunits }\end{array}$ & Glioblastoma & \\
\hline LICAM $^{229,230}$ & L1 Cell Adhesion molecule & Glioma stem cells & $A \smile$ \\
\hline $\begin{array}{l}\text { Mage- } 1^{29,50,132,183,} \\
221,222,231\end{array}$ & Melanoma Antigen-1 & bblastoma & $\begin{array}{l}\text { DC vaccine pulsed with } \\
\text { HER2, TRP-2, gp100, } \\
\text { MAGE-1, IL13R } 22 \text {, and } \\
\text { AIM-2 peptides } \\
\text { 33\% immune response }{ }^{132} \\
\text { DC vaccine pulsed with } \\
\text { WT-1, HER2, MAGE-A3, } \\
\text { and MAGE-A1 or gp } 100 \\
\text { 66\% cellular immune } \\
\text { response } e^{221}\end{array}$ \\
\hline Mage- $3^{221,231}$ & Melanoma & Adult GBM, Neuroblastoma & $\begin{array}{c}\text { DC vaccine pulsed with } \\
\text { WT-1, HER2, MAGE-A3, } \\
\text { and MAGE-A1 or gp100 } \\
\text { 66\% cellular immune } \\
\text { response }\end{array}$ \\
\hline MART-1 $1^{29,183}$ & $\begin{array}{l}\text { Melanoma antigen } \\
\text { recognized by T-cells }\end{array}$ & $\begin{array}{l}\text { Low expression in adult and } \\
\text { pediatric brain tumors }\end{array}$ & N/A \\
\hline & $\begin{array}{l}\text { Multidrug Resistance } \\
\text { Protein-3 }\end{array}$ & Adult GBM & $\begin{array}{l}\text { Personalized peptide vaccine } \\
\text { mix containing MRP3 } \\
\text { peptide } \\
\text { 83\% peptide-specific CTL } \\
\text { response to at least one } \\
\text { peptide }\end{array}$ \\
\hline Nestin $_{234}^{197,198,215,231,}$ & Nestin & $\begin{array}{c}\text { Glioma stem cells, } \\
\text { Glioblastoma, Astrocytoma }\end{array}$ & N/A \\
\hline NY-ESO-1 $1^{231,235}$ & $\begin{array}{l}\text { New York esophageal } \\
\text { squamous cell }\end{array}$ & Neuroblastoma & $\begin{array}{l}\text { CDX } 1401 \text { vaccine: DEC- } \\
205 \text { antibody linked to NY- } \\
\text { ESO-1 (NCT00948961) } \\
\text { 79\% NY-ESO-1-specific }\end{array}$ \\
\hline
\end{tabular}




\begin{tabular}{|c|c|c|c|}
\hline & carcinoma 1 & & $\begin{array}{c}\text { antibody response, } 56 \% \mathrm{NY} \text { - } \\
\text { ESO-1-specific T cell } \\
\text { response }^{235} \\
\text { CDX-1401 vaccine } \\
\text { (NCT00948961) ongoing }\end{array}$ \\
\hline Olig $2^{215,236-238}$ & $\begin{array}{l}\text { Oligodendrocyte } \\
\text { transcription factor } 1\end{array}$ & $\begin{array}{l}\text { Glioma stem cells, } \\
\text { Oligodendroglioma, } \\
\text { Oligoastrocytoma }\end{array}$ & \\
\hline Prox $1^{239}$ & Prospero homeobox protein 1 & $\begin{array}{l}\text { High grade glioma (also in } \\
\text { immature neurons) }\end{array}$ & \\
\hline PTH-rP ${ }^{29}$ & $\begin{array}{l}\text { Para-Thyroid Hormone- } \\
\text { related Protein }\end{array}$ & Adult GBM & N/A \\
\hline $\operatorname{PSCA}^{240}$ & $\begin{array}{c}\text { Prostate stem cell antigen, } \\
\text { GPI-anchored cell surface } \\
\text { protein }\end{array}$ & WHO grade & $\mathrm{N} / \mathrm{A}$ \\
\hline Sart- $1^{29,183}$ & $\begin{array}{c}\text { Squamous cell carcinoma } \\
\text { Antigen Recognized by } \mathrm{T} \\
\text { cells-1 }\end{array}$ & Astrocytoma, Adult GBM & $\mathrm{N} / \mathrm{A}$ \\
\hline Sart- $2^{29}$ & $\begin{array}{l}\text { Squamous cell carcinoma } \\
\text { Antigen Recognized by } \mathrm{T}\end{array}$ & Adult GBM & $\mathrm{N} / \mathrm{A}$ \\
\hline Sart- $3^{29}$ & $\begin{array}{l}\text { Squamous cell carcinoma } \\
\text { Antigen Recognized by } \mathrm{T}\end{array}$ & Adult GBM & $\mathrm{N} / \mathrm{A}$ \\
\hline Sox $2^{241,242}$ & $\begin{array}{l}\text { SRY (sex determining region } \\
\text { Y)-box } 2\end{array}$ & Glioma stem cells & $\mathrm{N} / \mathrm{A}$ \\
\hline 3 & $\begin{array}{l}\text { (sex determining region } \\
\text { Y)-box } 6\end{array}$ & Glioma stem cells & $\mathrm{N} / \mathrm{A}$ \\
\hline & $\begin{array}{l}\text { SRY (sex determining region } \\
\text { Y)-box } 10\end{array}$ & $\begin{array}{l}\text { Oligodendroglioma, } \\
\text { Oligoastrocytoma }\end{array}$ & $\mathrm{N} / \mathrm{A}$ \\
\hline Sox $11^{29,209,244}$ & $\begin{array}{c}\text { SRY (sex determining region } \\
\text { Y)-box } 11\end{array}$ & $\begin{array}{l}\text { Adult and pediatric brain } \\
\text { tumors }\end{array}$ & $\mathrm{N} / \mathrm{A}$ \\
\hline $\mathrm{SSEA}^{245}$ & Stage-Specific Embryonic & Glioma stem cells & $\mathrm{N} / \mathrm{A}$ \\
\hline
\end{tabular}




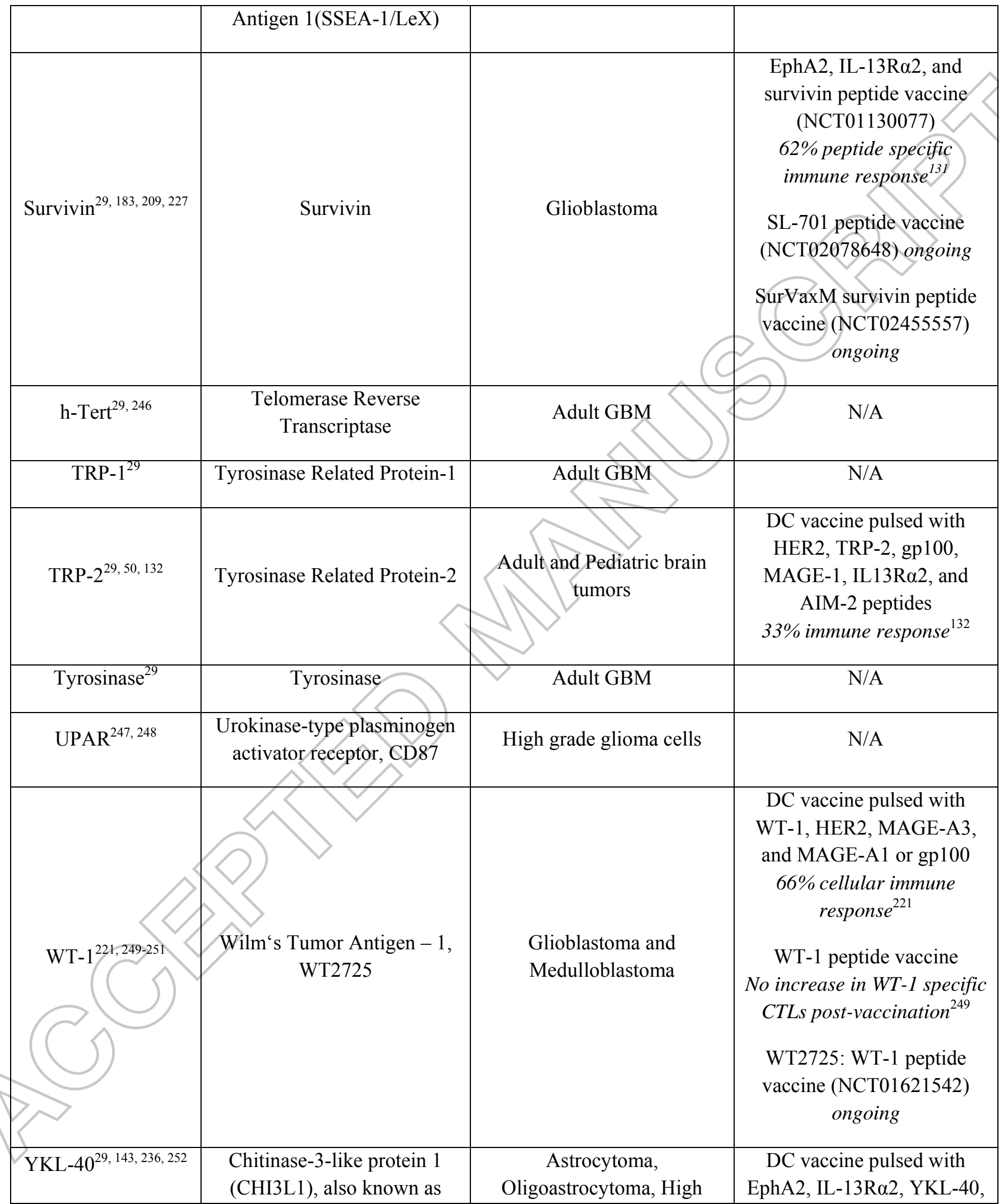




\begin{tabular}{|c|c|c|c|}
\hline YKL-40 & $\begin{array}{c}\text { grade glioma, Glioma Stem } \\
\text { Cells, secreted biomarker } \\
\text { present in the serum of } \\
\text { glioblastoma patients, Adult } \\
\text { and pediatric brain tumors }\end{array}$ & $\begin{array}{c}\text { and gp100 (NCT00766753) } \\
58 \% \text { immune response }\end{array}$ \\
& & $\begin{array}{c}\text { Peptide vaccine with } \\
\text { EGFRvIII, IL-13Ra2, } \\
\text { EphA2, Her2/neu,YKL-40 } \\
\text { peptides (NCT02754362) } \\
\text { ongoing }\end{array}$ \\
& & \\
\hline
\end{tabular}


Table 3: Key factors that impact the efficacy of cancer vaccines for GBM patients

\begin{tabular}{|c|c|}
\hline Strategy & Items \\
\hline $\begin{array}{l}\text { Generation of tumor } \\
\text { antigens }{ }^{143,144,221,253-} \\
259\end{array}$ & $\begin{array}{l}\text { CMV pp65 RNA, IDH1(R132H), WT1, EGFRvIII, IL13R-a2, } \\
\text { H3F3A(K27M), autologous tumor lysate, HSPPC-96, cocktail of peptides }\end{array}$ \\
\hline $\begin{array}{l}\text { Delivery of tumor } \\
\text { antigens }^{87,260-263}\end{array}$ & systemic injection of antigens, dendritic cells, (viral vector) \\
\hline $\begin{array}{l}\text { Adjuvant }^{142,174,264,} \\
265\end{array}$ & $\begin{array}{l}\text { tetanus, KLH, ISA51, imiquimod, polyICLC, (anti-PD-1 Ab, anti-CTLA4 Ab, } \\
\text { anti-Gr1 MDSC inhibitor, IDO inhibitor) }\end{array}$ \\
\hline $\begin{array}{l}\text { Stratification of } \\
\text { patients }^{142,169,170}\end{array}$ & pSTAT signaling, mesenchymal gene expression signature, TCR \\
\hline
\end{tabular}

GBM, glioblastoma; CMV, cytomegalovirus; pp65, phosphoprotein 65; IDH1, isocitrate dehydrogenase 1; WT1, Wilms tumor 1; EGFR, epidermal growth factor receptor; HSPPC, heat shock protein peptide complex; PD-1, programmed death 1; CTLA4, cytotoxic lymphocyte antigen 4; MDSC, myeloid derived suppressor cell; IDO, indoleamine 2,3-dioxygenase; STAT, signal tranducer and activator of transcription; TCR, T cell receptor.Adjuvants in the parenthesis have not been tested in human trials.

\section{ARTICLE HIGHLIGHTS BOX}

- Molecular features of gliomas such as 1p/19q co-deletion, IDH1 mutation, mutation in TERT gene and loss of ATRX are increasingly used in the diagnosis of tumor samples and are predictive of histological sub-type and prognosis.

- GBM TME is highly immunosuppressive because of the presence of cells such as Tregs, MDSCs and TAMs, secretion of IL-10 and TGF- $\beta$ by GBM cells, differential regulation of HLA 
molecules on GBM cells and through the expression of $\mathrm{T}$ cell suppressive molecules such as CD80 and PDL1. Thus multipronged strategies are needed to overcome the GBM induced immune suppression effectively.

- Immunotherapeutic strategies targeting GBM can be broadly classified as immunomodulatory approaches, active immunotherapy, passive immunotherapy and adoptive immunotherapy using autologous T cells and CAR T cells.

- Immunomodulatory approaches target immunosuppressive checkpoints such as CTDA-4 and PD1. A clinical trial evaluating Ipilimumab for recurrent and newly diagnosed GBM is currently recruiting patients (NCT02017717). Another immunomodulatory therapy utilizes gene therapy. The conditionally cytotoxic-immune-stimulatory gene therapy approach developed in our laboratory, has proven to be highly efficacious in several rat and mouse intracranial GBM models and is currently being tested in the clinic (NCT01811992).

- Active immunotherapy aims at stimulating innate and adaptive immune responses against tumorspecific antigens. Several known tumor associated antigens such as HER-2, TRP-2, gp100, MAGE-1, IL-13 $\alpha 2$, EphA2 and AIM-2, are being targeted in GBM. Neoantigens such as EGFRvIII are increasingly being used to generate tumor specific responses. Mutant IDH1 peptide-derived vaccine PEPIDH1M is being tested in patients with IDH1 positive recurrent grade II glioma (NCT02193347) and the NOA-16 trial is a Phase I trial of IDH1 peptide vaccine for grade III-1V gliomas (NCT02454634).

- Adoptive immunotherapy using autologous T cell transfer and CAR T cells is also being tested. A phase I trial will test the safety and efficacy of using HER2-specific CARs in patients with recurrent GBM (NCT02442297). The Rosenberg group at NCI (NCT01454596) and the University of Pennsylvania/Novartis (NCT02209376) are also currently recruiting participants to test the safety and feasibility of administering T cells expressing anti-EGFRvIII CAR to GBM patients who have had their first recurrence or have residual disease after initial resection. 